\title{
Varieties of indebtedness: Financialization and mortgage market institutions in Europe
}

\author{
Tod Van Gunten ${ }^{\mathrm{a}, *}$, Edo Navot ${ }^{\mathrm{b}}$ \\ ${ }^{a}$ University of Edinburgh, Chrystal Macmillan Building, 15a George Square, Edinburgh EH8 9LD, United Kingdom \\ ${ }^{\mathrm{b}}$ Columbia University, Institute for Social and Economic Research and Policy (ISERP), International Affairs Building, 420 West 118th St, Suite 370, \\ Mail Code 3355, New York, NY 10027, United States
}

\section{A R T I C L E I N F O}

\section{Keywords:}

Financialization

Institutions

Household debt

\begin{abstract}
A B S T R A C T
During the global housing boom that preceded the 2007-9 financial crisis, household debt in creased substantially in many European countries, posing a challenge for literature on financialization and the institutional heterogeneity of mortgage markets. This paper examines recent institutional shifts in European mortgage markets and specifies three analytically distinct models of debt accumulation: inclusion, extension and intensity. While existing research has emphasized inclusion (access to homeownership), we show that financial intensification is an important determinant of cross-national variation in debt. We assess the variation in financial intensity in six European countries (France, Germany, Italy, the Netherlands, Portugal and Spain) using household-level survey data. Our results show that inclusion and expansion explain only part of the cross-national variation in mortgage debt to income ratios. Furthermore, household financial behavior is consistent with the financial intensity model, and variation in the degree of financial intensification explains a substantial portion of the cross-national difference in debt levels.
\end{abstract}

\section{Introduction}

The global financial crisis of 2007-2009 had its roots in a rapid expansion of mortgage credit and associated growth in household debt (Mian and Sufi, 2014). Though prominently associated with the "subprime" mortgage market in the United States, the debt expansion was not uniquely American: the housing boom was global in scope but varied in impact. In countries as diverse as Australia, Portugal, Norway and the Netherlands, household debt rose faster and reached higher levels than in the United States (see Fig. 1). This cross-national variation in household debt poses a puzzle for the emergent literature on the impact of "financialization" processes on households (van der Zwan, 2014; Fligstein and Goldstein, 2015; Davis, 2009; Krippner, 2011) and the economic sociology (and political economy) of credit and debt (Prasad, 2013; Carruthers and Ariovich, 2010; Schelkle, 2012a; Fuller, 2016; Schwartz and Seabrooke, 2009). While this body of work sheds important light on the institutional determinants of household debt levels, recent institutional changes in European mortgage markets and household financial behavior have not been adequately studied. Moreover, this literature has not sufficiently delineated processes which affect the proportion of debtors in society from those which impact the volume of debt among debtors; that is, the difference between more households borrowing and households borrowing more. We show that differential financial intensity facilitated by the heterogeneous transformation of European mortgage markets plays a central role in cross-national variation in household debt.

\footnotetext{
* Corresponding author.

E-mail address: tvangun@ed.ac.uk (T. Van Gunten).
} 


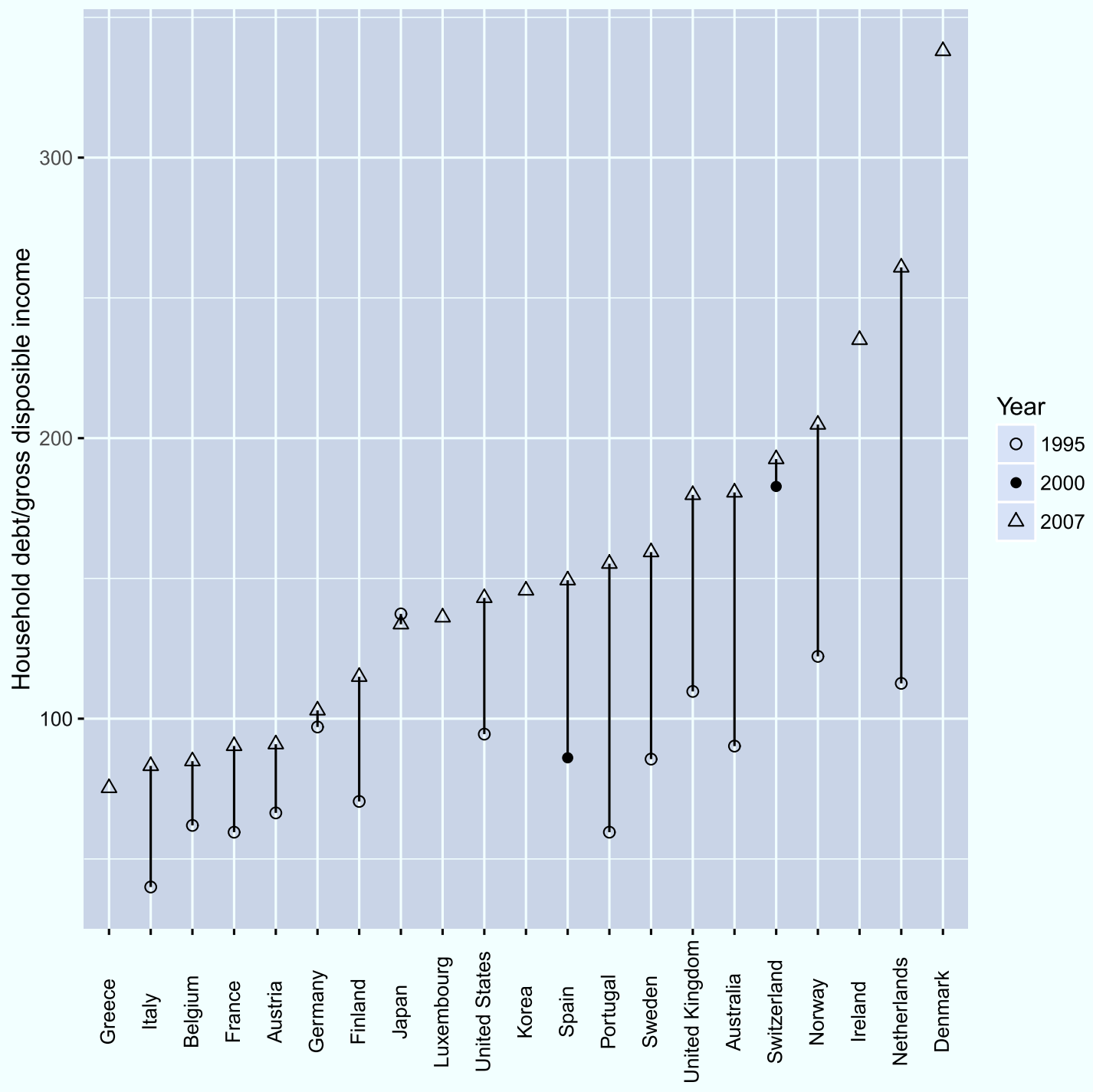

Fig. 1. Household debt/gross disposable income (data: OECD).

Because mortgage debt makes up the largest share of household debt (around 80\% in most European countries), mortgage and housing markets play the pivotal role in total debt burdens. Many existing institutional accounts of household debt levels invoke financial inclusion and extension models according to which debt levels primarily reflect homeownership rates and access to credit. In contrast, the analytically distinct financial intensity model stresses that rising debt burdens are partially independent of homeownership rates and credit access. On this model, households borrow more (generally in response to rising housing prices), often by drawing on higher-risk financial contracts, raising the probability that debt payments become a hardship. Policy and other institutional frameworks make intensification possible by influencing the availability of particular mortgage contracts, such as longterm loans, second mortgages, and refinancing opportunities that allow households to extract home equity.

The main contributions of this paper are to analytically specify these distinct models of debt accumulation, demonstrate that financial intensification is a key determinant of variation in household debt, and show how institutional shifts in European mortgage markets have enabled this intensification to take place. We use recent microdata to examine the borrowing behavior of households in six countries: France, Germany, Italy, the Netherlands, Portugal and Spain. Debt levels in these countries range from very high (the Netherlands, with the second highest level of debt among OECD countries) to comparatively low (Italy, with the second lowest level in Western Europe). The Netherlands is particularly interesting because it avoided a mortgage market crisis despite its high debt level, while Spanish and Portuguese households suffered rising loan delinquency rates during the financial crisis. Germany is unique among developed countries in that household debt levels actually fell during the global housing boom. These six countries therefore illustrate the varieties of indebtedness corresponding to distinct institutional configurations of mortgage markets, household behavior, and 
aggregate debt.

We demonstrate the importance of financial intensification in two ways. First, microdata show that the median mortgage debtor in "high debt" countries is more indebted than in "low debt"countries: in other words, conditional on having a mortgage, these homeowners also borrow more. Moreover, we conduct counter-factual simulations showing that extension and inclusion can explain at most one-third of the gap between "high debt" Spain and Portugal and "low debt" France and Germany, though extension is a key part of the explanation for the low level of debt in Italy. Second, multivariate models show that micro-institutional characteristics of mortgage markets have permitted greater financial intensification in Spain and Portugal relative to France and Germany; in the latter case, households have actually undergone a process of financial de-intensification that is unique among European countries. The results also show that there are distinct varieties of indebtedness hidden beneath aggregate debt levels: for example, while mortgage markets have permitted some forms of financial intensification in Italy, the extension of mortgage credit is constrained by institutional factors such as the inefficient legal system. Conversely, the high level of Dutch household debt reflects a variety of indebtedness corresponding to the unique macro institutional configuration of the mortgage market not captured in our models.

\section{Models of household debt accumulation: Financial inclusion, extension and intensity}

Recent research has begun to examine the connection between mortgage debt, housing markets, and the institutional heterogeneity of political economies (Schelkle, 2012b; Trumbull, 2012; Schwartz and Seabrooke, 2009; Prasad, 2013; Fuller, 2015, 2016). For example, Prasad (2013) argues that "mortgage Keynesianism" is a core feature of the U.S. political economy, which sustains consumption by broad credit access rather than welfare provision. Similarly, Schelkle (2012a, b) argues persuasively that "financial" policies ranging from regulations on credit access to personal bankruptcy legislation are also social policies, insofar as they affect the accessibility, costs and risks of homeownership. Others have proposed typologies of "varieties of residential capitalism" that extend the "worlds of welfare" and varieties of capitalism literature (Schwartz and Seabrooke, 2009).

This paper addresses two important empirical and theoretical limitations in this growing literature. First, these institutional accounts give a static depiction of a rapidly changing reality in many European countries. For example, while Germany had higher household debt than the US at the beginning of the 2000s, German households are now among the least-indebted in wealthy countries. Conversely, countries including Spain and Ireland rapidly rose in the global distribution of household debt during the 2000s. High debt levels in Scandinavia, the Netherlands and Iberian Europe undermine the "American exceptionalism" implicit in accounts which treat the U.S. mortgage market as unique (Prasad, 2013; Schwartz, 2009). Moreover, recent institutional shifts challenge accounts that rest on static institutional indicators and data from the 1990s or early 2000s (Fuller, 2015; Schwartz and Seabrooke, 2009; Andrews et al., 2011; International Monetary Fund, 2008). While illuminating in many respects, these static comparisons deemphasize recent processes of liberalization and financialization, and therefore cannot account for increasing debt of households in many European countries, nor the uniquely declining German debt.

Second, existing literature tends to confound three analytically distinct models of household debt accumulation. In particular, it is critical to distinguish between more households borrowing (the proportion of mortgage debtors in society) and households borrowing more (rising debt burdens conditional on borrowing). Given the central role of mortgage markets in overall household debt, there are three distinct processes that may explain cross-national and longitudinal variation in household debt levels. First, variations in debt may reflect differences in homeownership rates, which we refer to as the inclusion model. Second, holding homeownership constant, rates of participation in the mortgage market (relative to alternative means of achieving homeownership) is a second potential factor. We refer to this as the extension model of debt accumulation. Both inclusion and extension models focus on more households borrowing. Third, holding both homeownership and participation in the mortgage market constant, households may borrow more on average, which we refer to as the intensity model of debt accumulation. The main goal of this paper is to study how institutional variations in mortgage markets facilitate or discourage financial intensity.

Much of the recent comparative work on household debt in sociology and political economy focuses on the inclusion model, that is, the connection between homeownership rates and aggregate debt levels (Prasad, 2013; Schwartz and Seabrooke, 2009; Schelkle, 2012 b). For example, the claim that "in making homeownership easier to obtain by making debt easier to take on and to manage, the United States is unparalleled" (Prasad, 2013: 201) invokes this model. This emphasis reflects the intuitive relationship between homeownership rates and aggregate debt levels: all else constant, assuming that most household borrow to purchase a home, increasing the homeownership rate has a mechanical effect on the aggregate debt level. Because this link is so intuitive, it is surprising that homeownership rates are uncorrelated with debt levels in recent years: the correlation between the aggregate debt/income ratio and the national homeownership rate in country-level data is close to zero (0.04), implying that higher debt is not a reliable indicator of a more inclusive housing market. ${ }^{1}$ This reflects the fact that some countries with high homeownership rates, such as Greece, Italy and Belgium, have relatively low household debt levels, while many countries with high debt levels - such as the Netherlands, Denmark and Switzerland - do not have high homeownership rates. For example, Switzerland and Germany have similar low homeownership rates, but Switzerland has one the highest debt levels in the world, while German debt is now comparative low.

The extension model has received less consistent attention in recent literature. According to this model, differences in rates of participation in the mortgage market (rather than homeownership per se) are a key driver of the proportion of debtors in society, and thus the aggregate debt level. In societies where the cost of housing is low or intra-familial mechanisms of housing provision are prevalent, households may achieve homeownership without relying on mortgage credit. In keeping with the extension model,

\footnotetext{
${ }^{1}$ Our calculation using OECD data on debt/income and homeownership data from Eurostat and the US Federal Reserve corresponding to 2007.
} 
political economists have argued that Mediterranean countries combine high homeownership with low rates of borrowing due to inter-generational channels of housing provision, sometimes called the "Catholic-familial" housing model (Allen et al., 2008; Schwartz and Seabrooke, 2009). Aggregate data offer some prima facie support for this model: country-level European data show a strong correlation (0.68) between the proportion of households holding a mortgage and aggregate household debt. ${ }^{2}$ Similarly, among households that acquired their residences before the mid-1990s, a lower proportion of homeowners in Spain and Italy used a mortgage to acquire their first home than most Northern European countries (Angelini et al., 2013). However, the dramatic increase of debt on the Iberian peninsula raises the question of whether this model remains valid. We show that two Southern European countries (Spain and Portugal) have broken away from the "Catholic-familial" model. Furthermore, our counterfactual analysis shows that differences in the proportion of debtors accounts for at most $30 \%$ of the debt gap between the Iberian countries and France and Germany, though mortgage market extension is an important piece of the explanation for Italy's low aggregate debt level. This shows that a substantial portion of the variation in debt across countries is not explained by either inclusion or extension.

The intensity model focuses on the debt burdens of households conditional on participation in the mortgage market (thus holding both homeownership and mortgage holding constant). Households have borrowed more in relation to income in recent years for at least two reasons. First, during the global credit boom, house prices rose rapidly in real terms in many countries; in order to achieve homeownership in this context, households had to borrow more relative to income. Second, rapid housing price increases can result in a wealth effect, encouraging households to use their homes as leverage to fund current consumption (Mian and Sufi, 2011). However, households can only increase their financial leverage if mortgage lenders are willing to lend more; this willingness depends on the institutional framework governing mortgage markets, as we discuss in the next section. Financial intensification generally implies increased financial risk for homeowners in two ways: first, borrowing more can be risky in itself because households are more exposed to price fluctuations and declining incomes; second, lenders are often only willing to extend larger loans on the condition that households accept riskier terms.

Recent research on the impact of financialization on households examines financial intensification primarily in the US and UK (Davis, 2009; Fligstein and Goldstein, 2015; Langley, 2008). The argument that US "homeowners [see] their home as just another financial asset, a piggy bank to fund a new flat screen television" (Davis, 2009: 26) implies one form of intensification. Similarly, much of the literature on the subprime crisis mixes inclusion and intensity models; for example, to the extent that subprime lenders target borrowers without previous access to the mortgage market, these borrowers might borrow more relative to their income and at riskier conditions, implying intensification (Williams et al., 2005; Rugh and Massey, 2010). While some of this literature adopts a cultural lens that emphasizes shifting financial "mentalities," "idioms" (Davis, 2009: 6, 27) and "repertoires" (Fligstein and Goldstein, 2015), we stress that financial intensity is dependent on the willingness of lenders to facilitate this behavior, and thereby to the institutional configuration of mortgage markets. ${ }^{3}$

These distinct models of household debt accumulation are not mutually exclusive, and we do not suggest that authors who have emphasized inclusion deny the importance of extension or intensity. However, the analytical distinction between inclusion, extension and intensity deserves more attention because of the divergent social implications of these models. The financial inclusion model implies a "democratization of credit" (Prasad, 2013: ch. 8) which creates social benefits in the form of higher homeownership rates. Similarly, to the extent that rising debt reflects the replacement of paternalistic intra-familial transfers by formal credit markets, rising debt levels might represent an increase in individual freedom. However, the social benefits of financial intensification are less clear. Households who borrow heavily and on riskier terms may become over-indebted and exposed to housing price fluctuations and other risks, increasing the probability of default and foreclosure (Immergluck, 2009). Increasing flows of mortgage credit put upwards pressure on housing prices, setting a price-debt-price feedback cycle into motion which undercuts wealth accumulation by increasing household leverage. Thus, the social implications of debt depend on whether aggregate debt levels reflect a high concentration of debt burdens on a few households, or a broad distribution of debt indicating wide access to credit and homeownership.

Before exploring the links between financial intensity and institutional variation, we briefly consider two alternative explanations for household debt. First, several authors have argued that rising income inequality contributed to the U.S. subprime mortgage crisis (Rajan, 2010; Kumhof and Ranciere, 2010). Second, a related line of research focuses on a hypothesized tradeoff between welfare states and homeownership, arguing that lack of social protections drives households to seek homeownership as a form of selfinsurance, borrowing heavily in order to do so (Conley and Gifford, 2006; Prasad, 2013; Schwartz, 2012; Kemeny, 2005). From a comparative perspective, the problem with both arguments is the absence of a simple correlation between inequality or social spending and aggregate household debt. ${ }^{4}$ The fact that households in comparatively equal Northern European countries with generous welfare states - including the Netherlands, Denmark, Norway and Sweden — are among the most indebted in the world imply that high inequality and low welfare provision are not necessary conditions for high consumer debt. Morever, previous empirical studies have failed to find a direct link between inequality and household debt (Bordo and Meissner, 2012; Coibion et al., 2014). While there may be a more complex conditional relationship between debt and inequality applicable to the United States, from a cross-national perspective the explanatory leverage of these factors seems limited.

\footnotetext{
${ }^{2}$ Our calculation based on OECD debt/income data and mortgage market participation data in 2007 from Eurostat for 16 countries.

${ }^{3}$ Fligstein and Goldstein (2015) also argue that cultural shifts are rooted in material processes.

${ }^{4}$ Using OECD data on debt at the height of the global housing boom (2007 or the closest available year), we find correlations close to zero with both social spending and Gini coefficients.
} 
Table 1

Institutional characteristics.

\begin{tabular}{|c|c|c|c|c|c|c|}
\hline & France & Germany & Italy & Netherlands & Portugal & Spain \\
\hline \multicolumn{7}{|l|}{ Micro-institutional factors } \\
\hline Typical maturity & 19 & $25-30$ & 22 & 30 & $30-40$ & 30 \\
\hline Typical interest rate & Fixed & Fixed & Variable & Fixed & Variable & Variable \\
\hline Early repayment: law/contract & $\mathrm{L} / \mathrm{C}$ & $\mathrm{L} / \mathrm{C}$ & $\mathrm{L}$ & $\mathrm{C}$ & $\mathrm{L}$ & $\mathrm{L} / \mathrm{C}$ \\
\hline Equity withdrawal (allowed) & No & No & No & Yes & na & Limited \\
\hline \multicolumn{7}{|l|}{ Macro-institutional factors } \\
\hline Capital market funding & $12 \%$ & $14 \%$ & $20 \%$ & $25 \%$ & $27 \%$ & $45 \%$ \\
\hline Tax subsidies & 0.54 & 0 & 0.15 & 1.62 & 0.23 & 0.6 \\
\hline Foreclosure: duration (months) & 20 & 9 & 56 & 5 & 24 & 8 \\
\hline
\end{tabular}

\section{Institutional variation and financial intensity}

National institutional frameworks defined by public policy, historical legacies and industry norms shape households' financial options by influencing the characteristics of available mortgage contracts (Prasad, 2013; Schelkle, 2012b; Schwartz and Seabrooke, 2009; Fuller, 2015; International Monetary Fund, 2008). In this section, we give a first-cut account of this cross-national variation (abstracting from recent changes discussed in the next section) in order to extend previous work by developing competing hypotheses derived from financial inclusion and intensity models. Mortgage contracts vary in the extent to which they shift the costs and risks of homeownership from borrowers to creditors or third parties. Policy frameworks and other institutions intervene by influencing the degree to which banks and other creditors can manage the risks and costs of mortgage lending. These risks include default (the likelihood of non-payment), prepayment (the loss of profit due to early repayment), and maturity mismatch (the threat of financial insolvency that comes from funding long-term mortgage credit with short-term savings deposits). To the extent that creditors can transfer or manage these risks, they can offer relatively advantageous mortgage conditions to households. These conditions include long-term credit, fixed interest rates, easy refinancing and second mortgages; for example, Prasad (2013: 201) argues that these conditions create "a combination of characteristics that [make] the American home mortgage stand out" (c.f. Green and Wachter, 2005; Schwartz and Seabrooke, 2009; Fuller, 2015; International Monetary Fund, 2008)]. Table 1 reports these and other microinstitutional features of mortgage contracts as well as related macro-institutional regulations and financial technologies.

Sources: European Central Bank (2009): Maturity, early repayment, interest rate, bankruptcy, typical LTV, capital market funding; International Monetary Fund (2008): equity withdrawal; Andrews et al. (2011): tax subsidies; Bover et al. (2014): bankruptcy; LTV limit.

A first important source of institutional variation is the availability of long-term credit to households (Schwartz and Seabrooke, 2009). Table 1 shows that there is substantial variation across Europe in "typical" mortgage duration, ranging from around 20 years in France and Italy, 25 to 30 in Germany, and 30 and higher in Spain, Portugal and the Netherlands. Below, we illustrate the withincountry variation beneath these aggregate values. While mortgage duration is not regulated directly, the ability of mortgage lenders to extend long-term credit requires secondary markets on which to fund mortgage credit. The existence of these markets, in turn, depends on regulatory frameworks and other forms of state intervention. For example, in the United States, state intervention played a central role in the creation of secondary mortgage markets via Fannie Mae and other government-sponsored enterprises (Quinn, 2010); this enabled banks to extend the duration of credit from under ten years before the 1930s to the 30-year mortgage that became common in the postwar period (Green and Wachter, 2005: 94-96).

The availability of long-term credit has different implications under the financial inclusion and intensification models. Inclusion implies that long-term credit makes borrowing more affordable by extending repayment over a longer period, lowering monthly payments and thus enabling a wider range of households to achieve homeownership (International Monetary Fund, 2008). In contrast, the financial intensity model suggests that households use long-term credit to "stretch" their purchasing power in response to rising prices by spreading a larger volume of borrowing out over time, resulting in a higher stock of debt. ${ }^{5}$ To the extent that households use longer mortgages to borrow more, rather than reduce payments, long-term credit does little to foster inclusion while exposing households to greater risk.

A second source of institutional variation is the prevailing mechanism for setting interest rates. Relative to fixed-rate mortgages, adjustable-rate contracts shift interest rate risk from banks to households, which have little ability to manage these risks (Green and Wachter, 2005: 102). As Table 1 shows, there is significant variation across Europe: variable rates are ubiquitous in Spain and Portugal, for example, but relatively uncommon in France. The inclusion model implies that adjustable interest rates are an impediment to borrowing because households will limit risk by foregoing homeownership or curtailing borrowing (for example by choosing smaller, less expensive homes). In contrast, a possibility consistent with the financial intensification model is that households faced with rising prices disregard the macroeconomic risk of fluctuating interest rates. To the extent that the ability to shift risk towards borrowers makes lenders willing to lend more, the intensification model thus predicts that homeowners who borrow at adjustable interest rates will have higher debt. This is consistent with the substantial expansion of adjustable-rate mortgages during the subprime boom in the U.S. (Immergluck, 2009: 85-88).

\footnotetext{
${ }^{5}$ In principle, households could stretch their purchasing power while also reducing payments, but our results do not provide evidence of this.
} 
A third form of institutional variation is the regulatory framework governing the cost of prepayment, which affects the availability of refinancing (Prasad, 2013; Schelkle, 2012b; International Monetary Fund, 2008; Schwartz, 2009). Regulations which limit prepayment penalties vary significantly across European countries. Table 1 illustrates this institutional variation (albeit imperfectly) by showing whether prepayment is governed by law, contract or a combination of both. In principle, the greater the role of law in governing prepayment and refinancing, the less scope for mortgage refinancing. Because of these regulations, a number of sources suggest that refinancing is generally not available in many European countries, including France, Germany, Spain and Italy (Schelkle, 2012b; International Monetary Fund, 2008; Schwartz and Seabrooke, 2009). However, micro data show that by 2010 , more than $10 \%$ of mortgages in France, Spain and Portugal, and more than 35\% in Germany and the Netherlands, were used to refinance an earlier mortgage. Mortgage refinancing is not free in Europe, but this does not imply that it is non-existent.

Again, the inclusion and intensity models entail different effects of refinancing on household debt. The inclusion model implies that the availability of refinancing makes it easier for households to "manage" their debt (Prasad, 2013), thus increasing the accessibility of homeownership (c.f. Schelkle, 2012b: 70). This suggests that households use refinancing opportunities to obtain improved borrowing conditions, such as lower monthly payments. However, refinancing is also a means to tap the "piggy bank" of housing wealth (Davis, 2009: 26; see also Schwartz, 2009: 97-107). Thus, the intensification model implies that refinancing results in higher debt levels rather than lower payments.

Refinancing is only one channel through which households can leverage their homes in order to fund current consumption. While the explicit equity withdrawal contracts (such as home equity lines of credit) available in the U.S (Schwartz and Seabrooke, 2009). are uncommon in Europe, second mortgages and other channels of leverage are available. Using a methodology described below, we find that a substantial fraction of households report uses of mortgage credit other than purchase of the real estate asset secured by the mortgage. Similarly, macroeconomic estimates suggest that net equity withdrawals became positive in the mid-2000s in some countries, including Spain and the Netherlands (European Central Bank, 2009). Though these forms of equity withdrawal are sometimes mentioned in the context of inclusion-oriented arguments (e.g. Schelkle, 2012b), from an analytical standpoint equity withdrawal reflects intensification, rather than inclusion.

These micro-institutional characteristics of mortgage markets are closely related to the broader macro-institutional background. One of the most important factors governing these risk transfers is the existence of secondary mortgage markets, such as securitization markets. Table 1 shows that capital market funding for mortgage lending - use of covered bonds ${ }^{6}$ and mortgage-backed securities, rather than traditional deposits - is highest in Spain, followed by the Netherlands and Portugal. Securitization is a novel institutional phenomenon these countries, having grown from negligible levels in the late 1990s to among the highest levels in Europe (European Central Bank, 2009). In contrast, securitization markets in France remained incipient; even in Italy, capital market funding overtook French levels during the 2000s. German mortgage banks remained reliant on traditional covered bonds, which shift less risk off bank balance sheets than modern securitization. Thus, variations in the extent of securitization closely mirror the availability of long term credit, which we show is one of the primary factors shaping cross-national variation in debt levels.

Two other macro-institutional variables deserve discussion. First, tax policies — particularly mortgage interest subsides — affect the cost of bearing mortgage debt (Andrews et al., 2011; Fuller, 2015). Table 1 reports that the Netherlands has a generous system of tax incentives (indeed, tax relief is the greatest of any country in the OECD). As we show below, our results are consistent with the view that tax policy is a key factor driving the extreme level of Dutch household debt, as argued by country experts (e.g. Vandevyvere and Zenthöfer, 2012). In a broader set of countries, there is a moderate correlation of 0.36 between mortgage tax relief and household debt, suggesting that tax subsidies are important but not the only factor. Second, the legal difficulty of foreclosure is often cited as a constraint on household lending in Italy (Bover et al., 2014; Schwartz and Seabrooke, 2009). ${ }^{7}$ Again, our results are consistent with this argument in the Italian case.

The hypotheses just developed are summarized in Table 2. In general, we expect to see greater evidence consistent with the financial intensity model in countries where debt has expanded most in recent years, including (in our sample of countries) the Netherlands, Portugal, and Spain. In countries with less debt accumulation (such as France, Germany and Italy), we expect less evidence consistent with financial intensification. We test these hypotheses using household-level survey data which report debt levels and contractual features of mortgages. Most studies of the relationship between institutions and household financial behavior rely on small-N comparisons (Schelkle, 2012b; Fuller, 2016) or simple cross-sectional designs using additive institutional indexes based on information like that reported in Table 1 (Fuller, 2015; International Monetary Fund, 2008; Schwartz, 2009). In contrast, our methodology exploits the fact that the micro-institutional variation just discussed has observable implications at the household level. Mortgage market institutions shape the distribution of available contracts rather than binary characteristics of markets. For example, the "typical" mortgage duration abstracts from both cross-sectional and longitudinal variation within countries. Unlike aggregate approaches, micro-data permit a direct evaluation of the predictions of the inclusion and intensity models regarding household financial behavior; as we show empirically, for example, households use refinancing opportunities differently in different countries. While this approach cannot shed light on institutions which do not have observable correlates at the household level, this household-level variation provides insight into the processes driving household debt.

\footnotetext{
${ }^{6}$ Covered bonds are financial instruments which entitle their holders to claims on the stream of mortgage payments but which, unlike mortgage-backed securities, do not remove the mortgages from the issuing banks' balance sheet.

7 Bover et. al. (2014) find a correlation between legal efficiency and debt, but Italy is a clear outlier that drives this result.
} 
Table 2

Summary of hypotheses.

\begin{tabular}{lll}
\hline Mortgage market institution & Inclusion model hypothesis & Intensity model hypothesis \\
\hline Longer mortgage duration & lower mortgage payments & higher mortgage debt \\
Adjustable interest rates & lower mortgage debt & higher mortgage debt \\
Mortgage refinancing & lower mortgage payments & higher mortgage debt \\
Other equity withdrawal & - & higher mortgage debt \\
\hline
\end{tabular}

\section{Data and descriptive results}

Our primary data source is the Household Finance and Consumption Survey (HFCS), a household wealth survey conducted in 15 Eurozone countries between 2009 and 2011 and harmonized by the European Central Bank. The survey incorporates a stratified sampling methodology with an oversample of wealthy households; data are multiply imputed to address non-response (HFCN, 2013). For tractability, we selected three countries above the median debt level among OECD countries at the peak of the global credit boom in 2007 (the Netherlands, Portugal and Spain) and three countries below-median countries (France, Germany and Italy). The former are the only three countries with above-mean debt levels that are available in the HFCS data. In practice, due to variations in the questionnaire and other data limitations, our case selection excludes Greece, Luxembourg, Austria and Belgium, all countries with low debt levels.

In order to confirm the correspondence between these micro-data and debt aggregates based on national accounts, we first compute the ratio of total debt to total income (the survey-based analogue to the aggregate debt to income ratio) for all 13 countries for which both are available. We find a correlation of 0.96 , showing that survey and aggregate statistics show similar variation in debt levels. We also find a correlation between the aggregate debt to income ratio based on national accounts and the median mortgage to income ratio (calculated for homeowners with a mortgage) of $0.83 .^{8}$ This correlation is noteworthy because it shows that differences between homeowners with a mortgage mirror the cross-national variation manifest in national accounts. In other words, it is not only that there are more indebted homeowners in "high debt" countries; on average, Dutch, Spanish and Portuguese homeowners also borrow more relative to income than their German, French and Italian peers. This high correlation implies a very strong contribution of financial intensity to overall variation in household debt.

Nevertheless, aggregate statistics also show that financial extension (measured by the rate of participation in the mortgage market) is correlated with aggregate household debt, consistent with the "Catholic-familial" model (Allen et al., 2008; Schwartz and Seabrooke, 2009). In order to provide a more precise estimate of the relative contribution of financial inclusion, extension and intensity to debt levels, we conduct a counter-factual simulation to determine how much of the cross-national variation in household debt can be explained by differences in the proportion of debtors, reflecting either inclusion or extension. We seek to quantify the difference in debt to income ratios across countries that can be attributed to the fact that "low debt" countries simply have fewer households with mortgages. To do so, we simulate total debt/income ratios, counter-factually changing the proportion of mortgage debtors in each country while holding mean debt and income constant. ${ }^{9}$ We calculated the counter-factual mortgage debt/income ratios of France, Germany and Italy, as if they had the proportion of mortgage debtors prevailing in the Netherlands, Spain and Portugal. Mortgage market participation rates and other components of the counterfactuals are reported in Table 3; the appendix describes the counterfactual methodology in more detail.

We find that counterfactually increasing the mortgage market participation rate of "low debt" countries to that of "high debt" countries increases the debt to income ratio in the former by between 16\% and 37\% in France and Germany and 50\%-65\% in Italy (Table 4). Italy's extremely low debt to income ratio thus reflects, to a substantial extent, an extremely low rate of participation in the mortgage market (despite a high homeownership rate). However, the simulation shows that half or less of the gap between French and Germany debt and the "high debt" countries is explained by the proportion of debtors. This indicates that neither financial inclusion (higher homeownership rates) nor expansion (a higher mortgage market participation rate) due to familial or, demographic factors can fully explain aggregate debt levels. This implies in turn that intensification must explain a substantially large portion of the cross-national variation in debt.

In the remainder of this paper, our main dependent variables of interest are the household mortgage debt to income ratio (the outstanding balance of all mortgages standardized by yearly income) and the mortgage service to income ratio (the flow of mortgage payments, standardized by monthly income). ${ }^{10}$ We focus on mortgage debt rather than all debt for two reasons. First, according to the HFCS data, between $82 \%$ and $92 \%$ of all household debt in these countries is mortgage debt. Second, because we focus on microinstitutional characteristics of the mortgage market, the independent variables we study are only defined for households with mortgages.

As shown in the first panel of Fig. 2, the median mortgage/income ratio among mortgage debtors reveals relative levels of household debt similar to those found in the aggregate: debt is highest in the Netherlands, somewhat lower in Spain and Portugal, and

\footnotetext{
${ }^{8}$ This correlation excludes an outlier (Slovakia); including Slovakia the correlation is 0.7 .

${ }^{9}$ We use all debt for this analysis in order to maintain conceptual similarity with the aggregate data; however, because most debt is mortgage debt, the mortgage/ income and total debt/income ratios are highly correlated.

${ }^{10}$ Both measures employ the same income data; we simply divide income by 12 in the mortgage service measure to facilitate interpretation.
} 
Table 3

Descriptive statistics for counter-factual debt calculations.

\begin{tabular}{|c|c|c|c|c|c|c|}
\hline & France & Germany & Italy & Netherlands & Portugal & Spain \\
\hline Actual debt/income x 100 & 67.4 & 62.1 & 34.3 & 178.7 & 85.7 & 104.1 \\
\hline \multicolumn{7}{|l|}{ Mean income $(€)$ : } \\
\hline Non-property owner & 24,947 & 29,470 & 23,826 & 37,163 & 14,534 & 21,514 \\
\hline Property with mort & 50,815 & 71,360 & 49,722 & 52,803 & 27,915 & 40,206 \\
\hline Property, no mort & 40,286 & 47,739 & 36,373 & 49,615 & 19,082 & 28,491 \\
\hline \multicolumn{7}{|l|}{ Mean debt $(€)$ : } \\
\hline Non-property owner & 2048 & 2634 & 1520 & 11,981 & 1297 & 3893 \\
\hline Property with mortgage & 84,919 & 115,055 & 85,847 & 168,093 & 61,928 & 92,419 \\
\hline Property, no mortgage & 9156 & 3545 & 3440 & 12,695 & 1128 & 3760 \\
\hline \multicolumn{7}{|l|}{ Proportion of population: } \\
\hline Non-property owner & 0.39 & 0.51 & 0.28 & 0.42 & 0.25 & 0.14 \\
\hline Property with mortgage & 0.24 & 0.21 & 0.11 & 0.45 & 0.27 & 0.33 \\
\hline Property, no mortgage & 0.37 & 0.28 & 0.62 & 0.13 & 0.48 & 0.54 \\
\hline
\end{tabular}

Table 4

Counter-factual total debt to income ratios.

\begin{tabular}{|c|c|c|c|c|}
\hline & & France & Germany & Italy \\
\hline \multicolumn{5}{|c|}{ Counter-factual base } \\
\hline \multirow[t]{2}{*}{ Spain } & Counter-factual ratio & 78.9 & 75.1 & 76.9 \\
\hline & Percent change: & 0.31 & 0.31 & 0.61 \\
\hline \multirow{2}{*}{ Portugal } & Counter-factual ratio & 70.3 & 66.9 & 67.8 \\
\hline & Percent change: & 0.16 & 0.20 & 0.65 \\
\hline \multirow[t]{2}{*}{ Netherlands } & Counter-factual ratio & 103.9 & 104.7 & 106.5 \\
\hline & Percent change: & 0.33 & 0.37 & 0.50 \\
\hline
\end{tabular}

lowest in France, Germany and Italy. However, the median mortgaged homeowner in Italy has a slightly higher debt to income ratio than their French and German peers, despite the fact that aggregate debt is lower in Italy. This reflects what we have just shown: the low aggregate debt level in Italy is partly explained by an extremely low level of mortgage market extension. Still, the gap between median debt in Italy and in the Iberian cases indicates that Italian homeowners also borrow less on average; thus, the low Italian debt level is not entirely explained by financial extension.

The second panel of Fig. 2 shows that higher median debt levels do not necessarily imply higher debt payments: while the Netherlands has the highest outstanding stock of debt relative to income, median payments are the second-lowest after Germany, less than $15 \%$ of monthly income. This shows that repayment of these high levels of household debt is spread out over a longer period, implying that Dutch households take on less risk. Conversely, French and to a lesser extent Italian mortgage debtors face comparatively high payments, even though their debt levels are moderate. Spanish households face both high debt burdens and high payments, suggesting the greatest exposure to risk. Though median payments may seem low at first glance, payments levels are significantly skewed. $23 \%$ of mortgaged homeowners in Spain and $19 \%$ in Portugal have monthly payments above one third of monthly income. In contrast, despite the high median level of payments in France, only about 10\% of households (and slightly more in Italy) have similarly high payments. Thus, there are distinct varieties of indebtedness: high debt and high payments in Spain and Portugal, high debt and moderate payments in the Netherlands, low debt with moderate payments in France and Italy, and finally both low debt and payments in Germany.

\section{Institutional trends in mortgage markets}

As noted above, out analytical strategy exploits the fact that the institutional variation in mortgage markets shapes the distribution of available mortgage contracts, which is observable at the household level in the HFCS micro-data. We capture this variation using six main variables, defined in Table 5. Long-term borrowing, adjustable interest rates and refinancing are defined in a straightforward fashion. Net of equity extracted through refinancing, three additional variables capture the use of mortgage credit for purposes other than home purchase: second mortgages (excluding refinance mortgages), additional borrowing on existing mortgages after the residence was purchased, and a weighted index of borrowing intent. This final measure takes advantage of survey items which report the respondents' borrowing intent. For each mortgage, respondents stated the primary purpose of the loan and up to five additional purposes, including purchase of the property, purchase of other real estate and financing current consumption. This measure equals one in the hypothetical case that household uses mortgage credit exclusively for purposes other than property purchase, and zero if mortgages are used only for purchase.

In order to assess the institutional transformation of mortgage markets across Europe, Fig. 3 reports five-year moving averages of borrowing behavior based on the year debtors contracted or refinanced their primary mortgage. While these descriptives are based on a surveys conducted in a single year, because mortgage debt is intrinsically extended in time, debt levels among current debtors are a 

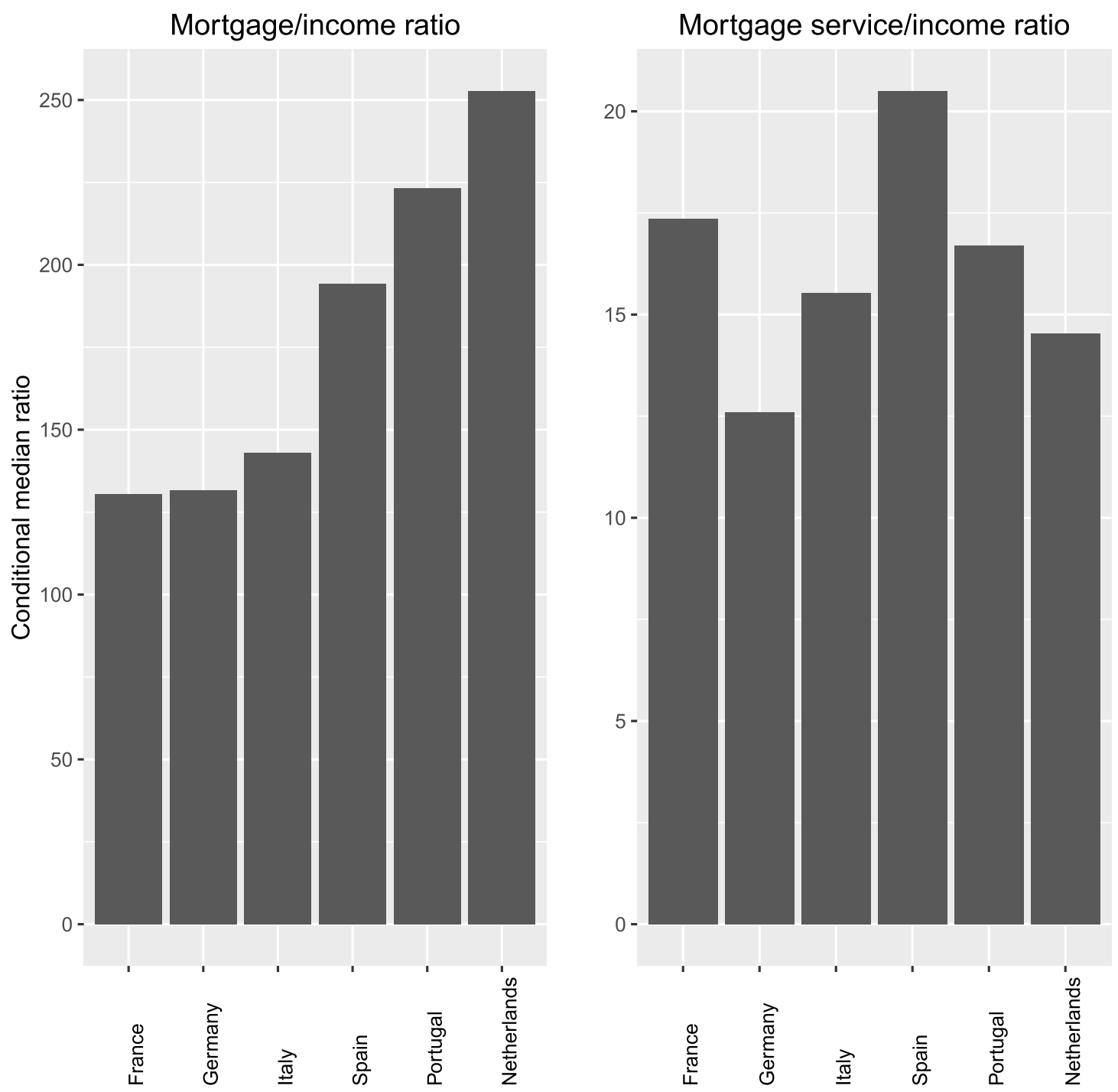

Fig. 2. Mortgage/income and Mortgage/service income ratios (HFCS data).

reflection of past behavior. It is important to emphasize two important points. First, these measures do not report the behavior of all borrowers in the past, but only those who continued to hold mortgage debt at the time of the survey. Second, the moving averages reflect lending activity in each period, not the stock of all outstanding mortgages. This approach permits meaningful inferences about the past behavior of current debtors (and only current debtors) during a period not greater than the duration of the average mortgage in each country; to avoid bias, we report only the 15 years prior to the survey.

Fig. 3 shows that there has been substantial institutional change in European mortgage markets, giving new contours to the crossnational variation discussed above. In high debt countries such as Spain and Portugal, borrowing duration rose substantially, reflecting the increasing availability of 30-year mortgages in these countries. In the Netherlands, in contrast, there is no obvious trend because long mortgages were already widely available in the 1990s. Mortgage duration also rose in France and Italy, but from lower levels and beginning only in the mid-2000s; by 2010, average mortgage maturities remained below 20 years. Finally, Germany is unique insofar as mortgage duration fell substantially from more than twenty years to only slightly more than 15 .

Second, the results illustrate important trends in the use of refinancing in Europe. In the mid-1990s, about 40\% of mortgage activity in France reflected refinancing; this proportion fell steadily during the global housing boom. Conversely, refinancing was relatively uncommon in Germany but increased dramatically; in the 2005-2010 period, roughly half of mortgages were refinance contracts. In Spain and Portugal, refinancing was practically non-existent in the mid-1990s and increased substantially; by the 2005-2010 period, $20 \%$ of mortgage contracts refinanced a previous mortgage. In contrast, in Italy mortgage refinance remained uncommon. Finally, in the Netherlands, refinancing was already moderately common in the mid-1990s and became increasingly 
Table 5

Variable definitions.

\begin{tabular}{|c|c|c|}
\hline Variable & Definition & Note \\
\hline \multicolumn{3}{|c|}{ Main financial variables } \\
\hline Duration & $\begin{array}{l}\text { Average duration of all mortgages at the time these loans were } \\
\text { contracted. }\end{array}$ & \\
\hline Adjustable rate & $\begin{array}{l}\text { First mortgage on main residence carries adjustable interest rate } \\
\text { (dummy) }\end{array}$ & $\begin{array}{l}\text { Second dummy included for households with more than one } \\
\text { adjustable interest rate loan. }\end{array}$ \\
\hline Refinancing & First mortgage on main residence refinanced (dummy) & Second dummy included for refinancing more than one mortgage. \\
\hline Second mortgage & $\begin{array}{l}\text { Household took out a mortgage more than one year after } \\
\text { purchasing main residence (excluding refinance mortgages) }\end{array}$ & Second dummy included for more than $1 \mathrm{~s}$ mortgage. \\
\hline $\begin{array}{l}\text { Additional } \\
\text { borrowing }\end{array}$ & $\begin{array}{l}\text { Household borrowed additional funds after mortgage was initially } \\
\text { contracted }\end{array}$ & $\begin{array}{l}\text { This behavior reported only in Germany, Portugal in Spain. In } \\
\text { Spain, this variable is highly correlated with refinancing and is } \\
\text { therefore omitted }\end{array}$ \\
\hline Loan purpose & $\begin{array}{l}\text { Weighted sum of the number of purposes for which the borrowed } \\
\text { funds were used other than purchase of the property on which the } \\
\text { mortgage is secured, averaged across all properties. }\end{array}$ & $\begin{array}{l}\text { The primary purpose } p_{1} \text { is given weight } w_{1}=\sqrt{1 / n} \text {, where } \mathrm{n} \text { is the } \\
\text { number of stated purposes, and } w_{p}>1=\frac{1-w_{1}}{n-1} \text {. The primary } \\
\text { purpose weight thus varies between } 0.71 \text { if the household states } \\
\text { two purposes and } 0.41 \text { if there are five purposes. Survey items not } \\
\text { available for France. }\end{array}$ \\
\hline \multicolumn{3}{|c|}{ Other financial variables } \\
\hline Other properties & $\begin{array}{l}\text { Number of properties other than main residence owned by } \\
\text { household }\end{array}$ & \\
\hline Other mortgages & Number of mortgages on other properties & \\
\hline \multicolumn{3}{|l|}{ Control variables } \\
\hline Income & Dummy variables for top and bottom income terciles & Comparison group: middle income tercile \\
\hline Age & $\begin{array}{l}\text { Dummy variables for age bracket of survey respondent, defined as } \\
\text { the household's "financially knowledgeable individual" }\end{array}$ & Comparison group: Age 35-44 \\
\hline Education & $\begin{array}{l}\text { Dummy variables for primary and tertiary education level of } \\
\text { survey respondent }\end{array}$ & Comparison group: Secondary education \\
\hline Earners & Dummy variables for zero and one-earner household & Comparison group: Couple \\
\hline Employment status & Dummy variable for one unemployed member of household & Comparison group: no household unemployment \\
\hline Years owned home & Number of years since household purchased home & \\
\hline
\end{tabular}

prevalent over time. These results contrast strongly with claims that mortgage refinancing is minimal in many European countries (International Monetary Fund, 2008).

Time trends are less pronounced for the proportion of households that held adjustable interest-rate debt. However, in contrast to the aggregate data reported in Table 1, micro data make it clear that adjustable interest rates predominate among current debtors in all three "high debt" countries. ${ }^{11}$ Moreover, these risk-bearing financial contracts became slightly more common in all three countries during the global housing boom. This contradicts the claim — based on the inclusion model — that these contracts are a deterrent to borrowing, and suggests that the willingness of households to accept macroeconomic risk may have enabled banks to lend more. Elsewhere, there was a substantial decline in proportion of households taking out adjustable-rate mortgage in Germany, and a significant increase in Italy. These results imply that German households uniquely bore declining interest rate risk, while Italians experienced the opposite tendency. Declining inflation in historically high-inflation Italy likely accounts for the latter trend.

The final panel of Fig. 3 reports one measure of housing-backed consumption, the extent to which households report using mortgages to fund current consumption. What is most important here is the somewhat surprising frequency with which households report using mortgage credit for purposes other than real estate purchase. In all countries except Spain (measure is unavailable for France) levels of this use of mortgage credit are substantial relative to the expectation that equity withdrawal is non-existent or limited. In Spain, levels are substantially lower but growing. While this is not a direct measure of equity withdrawal, it does suggest that households use mortgage credit for consumption purposes in a number of European countries.

\section{Multivariate analysis}

We now turn to a multivariate analysis of the impact of these institutional variables on household debt. These models control for several other aspects of the household's real estate wealth and demographic background, also described in Table 5. Models are specified such that the baseline household is an employed two-earner couple in the middle tercile of the income distribution with secondary education, aged 35 to 44. All variables are defined at the household (rather than individual) level; age and education refer to the primary respondent selected on the basis of their knowledge of the family's finances. We report OLS estimates of the determinants of the mortgage to income (Table 6) and mortgage service to income ratios (Table 7); estimations incorporate survey weights and boostrap standard errors which take survey design into account (HFCN, 2013). In order to check the sensitivity of our

\footnotetext{
11 The administrative data reported in Table 1 suggest that fixed interest rates are the dominant contract in the Netherlands. The discrepancy is likely explained by the fact that interest rates are fixed for the first decade or less of the life of the loan, but mortages are long-term contracts; thus, the modal Dutch mortgage has reverted to an adjustable interest rate.
} 

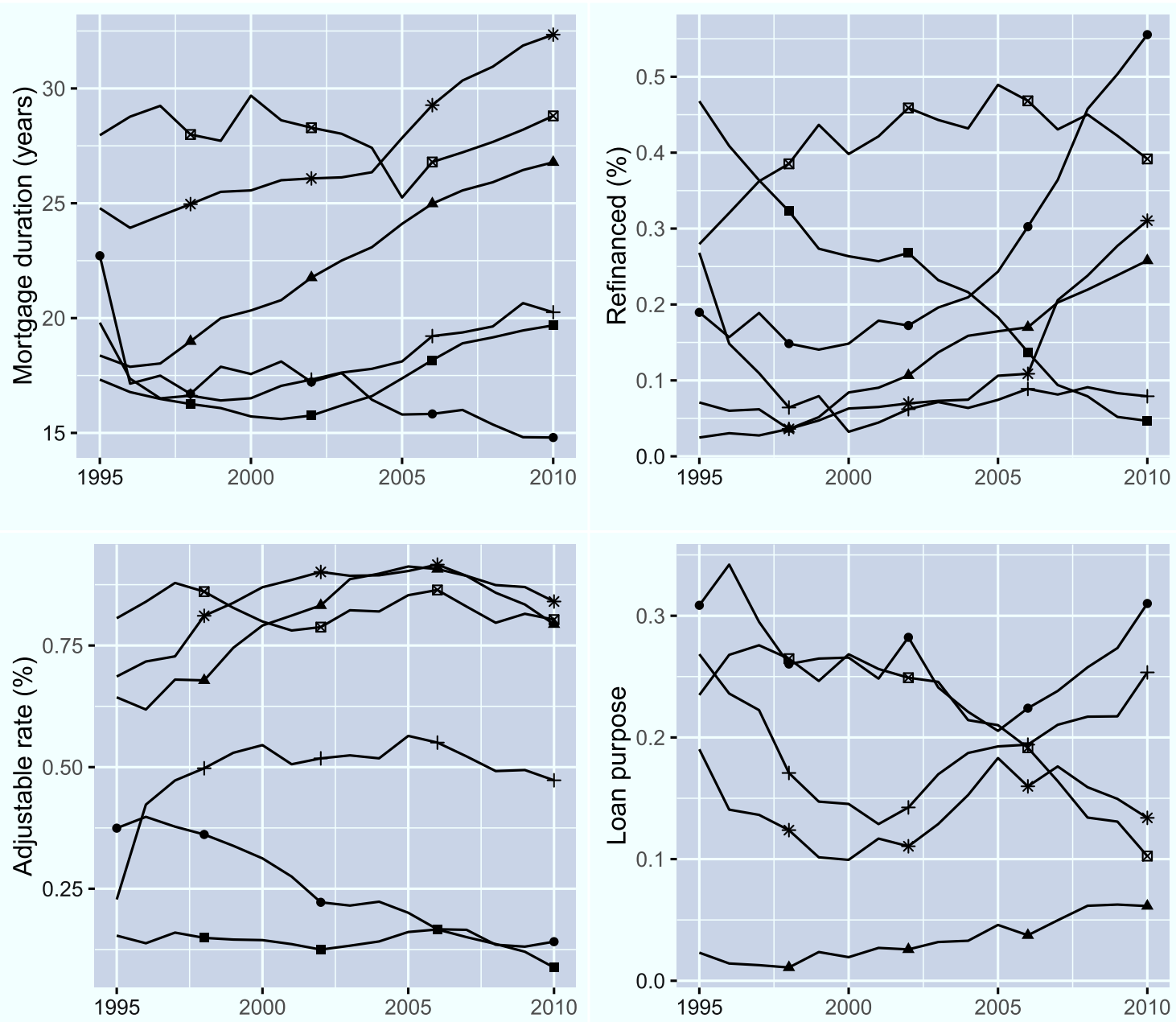

Country

- $\mathrm{DE}$ - FR $₫ \mathrm{NL}$

$\Delta \mathrm{ES}+\mathrm{IT} * \mathrm{PT}$

Fig. 3. Institutional trends in European mortgage markets (HFCS data).

models, we ran multiple robustness checks, including controls and sample restrictions for housing prices, attitudinal risk aversion, interest rates, and temporary income shocks; none of these modifications changes our basic results. Because implementation of the survey is decentralized, sample size varies across countries; results reported below reflect sample sizes ranging from 534 to 1992 households. The relatively small sample size reflects both the fact that mortgage debtors are a relatively small subset of households (around $20 \%$ in most countries) and missing data on key independent variables which were not imputed.

\subsection{Mortgage duration}

As argued above, financial inclusion implies that long-term credit helps households achieve homeownership by spreading repayment over a longer period, while financial intensity implies that long-term mortgages permit households to stretch their purchasing power in a context of increasing housing prices. Tables 6 and 7 support the intensity rather than inclusion model: in most countries (with the exceptions of Germany and the Netherlands), longer mortgages are significantly associated with higher debt, while in no country is longer-term borrowing significantly associated with lower debt payments. In two countries (France and Spain), long-term borrowing also results in higher monthly payments, showing the "stretching" effect makes mortgage debt less, rather than more "manageable." The variety of indebtedness most consistent with the inclusion model is the Netherlands, where long-term mortgages are accompanied by low median payments, though there is no evidence that households with longer mortgages have lower payments than those borrowing at shorter terms. 
Table 6

Determinants of mortgage/income ratio (OLS estimates; bootstrap standard errors in parentheses).

\begin{tabular}{|c|c|c|c|c|c|c|}
\hline & France & Germany & Italy & Netherlands & Portugal & Spain \\
\hline Duration & $\begin{array}{l}0.079 * * * \\
(0.006)\end{array}$ & $\begin{array}{l}0.004 \\
(0.009)\end{array}$ & $\begin{array}{l}0.084^{* * *} \\
(0.012)\end{array}$ & $\begin{array}{l}-0.004 \\
(0.007)\end{array}$ & $\begin{array}{l}0.034 * * * \\
(0.005)\end{array}$ & $\begin{array}{l}0.065^{* * *} \\
(0.008)\end{array}$ \\
\hline Adjustable rate & $\begin{array}{c}-0.007 \\
(0.091)\end{array}$ & $\begin{array}{c}-0.232 \\
(0.243)\end{array}$ & $\begin{array}{l}0.020 \\
(0.105)\end{array}$ & $\begin{array}{l}0.051 \\
(0.108)\end{array}$ & $\begin{array}{l}0.217^{*} \\
(0.098)\end{array}$ & $\begin{array}{l}0.083 \\
(0.116)\end{array}$ \\
\hline Refinanced & $\begin{array}{l}0.100 \\
(0.101)\end{array}$ & $\begin{array}{l}-0.119 \\
(0.190)\end{array}$ & $\begin{array}{l}0.470 * \\
(0.239)\end{array}$ & $\begin{array}{l}0.414^{* *} \\
(0.143)\end{array}$ & $\begin{array}{l}1.021^{* * *} \\
(0.302)\end{array}$ & $\begin{array}{l}0.605^{*} \\
(0.238)\end{array}$ \\
\hline Adjust. x Refin. & $\begin{array}{l}0.192 \\
(0.299)\end{array}$ & $\begin{array}{c}-0.556 \\
(0.305)\end{array}$ & $\begin{array}{l}0.479 * \\
(0.238)\end{array}$ & $\begin{array}{l}0.275^{*} \\
(0.108)\end{array}$ & $\begin{array}{l}0.539^{* * *} \\
(0.134)\end{array}$ & $\begin{array}{l}0.858^{* * *} \\
(0.196)\end{array}$ \\
\hline Second mortgage & $\begin{array}{l}0.436^{* * *} \\
(0.128)\end{array}$ & $\begin{array}{l}0.165 \\
(0.204)\end{array}$ & $\begin{array}{l}0.663^{* *} \\
(0.209)\end{array}$ & $\begin{array}{l}0.198 \\
(0.110)\end{array}$ & $\begin{array}{l}0.309 * * \\
(0.099)\end{array}$ & $\begin{array}{l}0.369 \\
(0.274)\end{array}$ \\
\hline Additional borrowing & - & $\begin{array}{l}0.017 \\
(0.216)\end{array}$ & - & - & $\begin{array}{l}0.288 * * \\
(0.093)\end{array}$ & - \\
\hline Loan purpose & - & $\begin{array}{c}-0.201 \\
(0.172)\end{array}$ & $\begin{array}{l}-0.043 \\
(0.232)\end{array}$ & $\begin{array}{l}0.262 \\
(0.144)\end{array}$ & $\begin{array}{l}0.128 \\
(0.156)\end{array}$ & $\begin{array}{l}0.855^{* *} \\
(0.269)\end{array}$ \\
\hline Refinanced $(>1)$ & $\begin{array}{l}0.736 \\
(0.409)\end{array}$ & $\begin{array}{l}0.739 * * * \\
(0.179)\end{array}$ & $\begin{array}{l}1.951^{* *} \\
(0.658)\end{array}$ & $\begin{array}{c}-0.039 \\
(0.154)\end{array}$ & $\begin{array}{l}-0.470 \\
(0.592)\end{array}$ & $\begin{array}{c}-0.564 \\
(0.662)\end{array}$ \\
\hline Adjust $(>1)$ & $\begin{array}{l}0.028 \\
(0.278)\end{array}$ & $\begin{array}{l}0.481 \\
(0.328)\end{array}$ & $\begin{array}{l}-0.101 \\
(0.698)\end{array}$ & $\begin{array}{l}0.130 \\
(0.117)\end{array}$ & $\begin{array}{l}0.239^{*} \\
(0.104)\end{array}$ & $\begin{array}{l}0.444 \\
(0.342)\end{array}$ \\
\hline Second mortgage $(>1)$ & $\begin{array}{l}0.136 \\
(0.183)\end{array}$ & $\begin{array}{l}0.545 \\
(0.329)\end{array}$ & $\begin{array}{l}-0.310 \\
(0.559)\end{array}$ & $\begin{array}{c}-0.077 \\
(0.211)\end{array}$ & $\begin{array}{l}0.576 \\
(0.311)\end{array}$ & $\begin{array}{l}0.358 \\
(0.695)\end{array}$ \\
\hline Other properties & $\begin{array}{l}-0.006 \\
(0.065)\end{array}$ & $\begin{array}{l}0.107 \\
(0.075)\end{array}$ & $\begin{array}{l}-0.012 \\
(0.066)\end{array}$ & $\begin{array}{l}0.271 \\
(0.244)\end{array}$ & $\begin{array}{l}0.035 \\
(0.042)\end{array}$ & $\begin{array}{l}0.078 \\
(0.051)\end{array}$ \\
\hline Other mortgages & $\begin{array}{l}0.643^{* * *} \\
(0.093)\end{array}$ & $\begin{array}{l}0.572^{* * *} \\
(0.106)\end{array}$ & $\begin{array}{l}0.575 \\
(0.518)\end{array}$ & $\begin{array}{l}1.311 * * \\
(0.487)\end{array}$ & $\begin{array}{l}0.509 * * * \\
(0.142)\end{array}$ & $\begin{array}{l}0.677^{* *} \\
(0.222)\end{array}$ \\
\hline \multicolumn{7}{|l|}{ Control variables } \\
\hline Low income & $\begin{array}{l}0.711^{* * *} \\
(0.147)\end{array}$ & $\begin{array}{l}0.864 * * \\
(0.317)\end{array}$ & $\begin{array}{l}0.723^{* *} \\
(0.260)\end{array}$ & $\begin{array}{l}0.714^{* * *} \\
(0.131)\end{array}$ & $\begin{array}{l}0.773 * * * \\
(0.117)\end{array}$ & $\begin{array}{l}0.780 * * * \\
(0.179)\end{array}$ \\
\hline Top income & $\begin{array}{l}-0.294 * * * \\
(0.068)\end{array}$ & $\begin{array}{l}-0.522^{* k *} \\
(0.119)\end{array}$ & $\begin{array}{l}-0.431^{* * *} \\
(0.116)\end{array}$ & $\begin{array}{l}-0.524^{* * *} \\
(0.079)\end{array}$ & $\begin{array}{l}-0.608^{* * *} \\
(0.069)\end{array}$ & $\begin{array}{l}-0.534 * * * \\
(0.083)\end{array}$ \\
\hline Age $16-34$ & $\begin{array}{l}-0.027 \\
(0.078)\end{array}$ & $\begin{array}{l}0.530^{* *} \\
(0.202)\end{array}$ & $\begin{array}{l}0.050 \\
(0.162)\end{array}$ & $\begin{array}{l}-0.018 \\
(0.139)\end{array}$ & $\begin{array}{l}0.144 \\
(0.074)\end{array}$ & $\begin{array}{l}0.285^{* *} \\
(0.103)\end{array}$ \\
\hline Age $45-54$ & $\begin{array}{l}-0.123 \\
(0.076)\end{array}$ & $\begin{array}{c}-0.057 \\
(0.148)\end{array}$ & $\begin{array}{l}-0.312^{*} \\
(0.143)\end{array}$ & $\begin{array}{l}-0.376^{* *} \\
(0.116)\end{array}$ & $\begin{array}{l}-0.173^{*} \\
(0.076)\end{array}$ & $\begin{array}{l}0.254^{*} \\
(0.113)\end{array}$ \\
\hline Age 55-64 & $\begin{array}{l}-0.297^{*} \\
(0.124)\end{array}$ & $\begin{array}{l}0.000 \\
(0.192)\end{array}$ & $\begin{array}{l}-0.111 \\
(0.203)\end{array}$ & $\begin{array}{l}-0.499 * * * \\
(0.147)\end{array}$ & $\begin{array}{l}-0.489 * * * \\
(0.119)\end{array}$ & $\begin{array}{l}0.284 \\
(0.203)\end{array}$ \\
\hline Age 64 & $\begin{array}{l}-0.105 \\
(0.190)\end{array}$ & $\begin{array}{l}-0.498^{*} \\
(0.233)\end{array}$ & $\begin{array}{l}-0.208 \\
(0.357)\end{array}$ & $\begin{array}{l}-0.562^{* * *} \\
(0.165)\end{array}$ & $\begin{array}{l}-0.652^{* *} \\
(0.232)\end{array}$ & $\begin{array}{l}0.040 \\
(0.208)\end{array}$ \\
\hline Educ: primary & $\begin{array}{l}-0.081 \\
(0.094)\end{array}$ & - & $\begin{array}{l}0.301 \\
(0.261)\end{array}$ & $\begin{array}{l}-0.355 \\
(0.412)\end{array}$ & $\begin{array}{l}0.118 \\
(0.069)\end{array}$ & $\begin{array}{l}0.275^{*} \\
(0.137)\end{array}$ \\
\hline Educ: tertiary & $\begin{array}{l}0.068 \\
(0.062)\end{array}$ & $\begin{array}{l}-0.013 \\
(0.095)\end{array}$ & $\begin{array}{c}-0.031 \\
(0.119)\end{array}$ & $\begin{array}{l}0.163 \\
(0.085)\end{array}$ & $\begin{array}{l}-0.100 \\
(0.086)\end{array}$ & $\begin{array}{l}0.119 \\
(0.094)\end{array}$ \\
\hline Single & $\begin{array}{l}-0.141 \\
(0.076)\end{array}$ & $\begin{array}{l}-0.010 \\
(0.223)\end{array}$ & $\begin{array}{l}0.091 \\
(0.157)\end{array}$ & $\begin{array}{l}-0.142 \\
(0.095)\end{array}$ & $\begin{array}{l}0.073 \\
(0.094)\end{array}$ & $\begin{array}{l}0.041 \\
(0.130)\end{array}$ \\
\hline Divorced & $\begin{array}{l}0.096 \\
(0.107)\end{array}$ & $\begin{array}{l}0.362 * \\
(0.180)\end{array}$ & $\begin{array}{l}-0.144 \\
(0.254)\end{array}$ & $\begin{array}{l}-0.173 \\
(0.163)\end{array}$ & $\begin{array}{l}0.200 * \\
(0.099)\end{array}$ & $\begin{array}{l}0.316 \\
(0.170)\end{array}$ \\
\hline No wage earners & $\begin{array}{l}0.093 \\
(0.237)\end{array}$ & $\begin{array}{l}0.081 \\
(0.275)\end{array}$ & $\begin{array}{l}-0.393 \\
(0.296)\end{array}$ & $\begin{array}{l}0.192 \\
(0.154)\end{array}$ & $\begin{array}{l}0.196 \\
(0.206)\end{array}$ & $\begin{array}{l}-0.020 \\
(0.167)\end{array}$ \\
\hline One wage earner & $\begin{array}{l}0.086 \\
(0.222)\end{array}$ & $\begin{array}{l}0.319 \\
(0.254)\end{array}$ & $\begin{array}{l}-0.579 \\
(0.326)\end{array}$ & $\begin{array}{l}0.072 \\
(0.144)\end{array}$ & $\begin{array}{l}0.188 \\
(0.172)\end{array}$ & $\begin{array}{c}-0.007 \\
(0.177)\end{array}$ \\
\hline Unemployed & $\begin{array}{l}0.081 \\
(0.123)\end{array}$ & $\begin{array}{l}-0.149 \\
(0.339)\end{array}$ & $\begin{array}{l}0.570 \\
(0.311)\end{array}$ & $\begin{array}{l}-0.016 \\
(0.237)\end{array}$ & $\begin{array}{l}0.089 \\
(0.131)\end{array}$ & $\begin{array}{l}0.062 \\
(0.147)\end{array}$ \\
\hline Years owned HMR & $\begin{array}{l}-0.127^{* * *} \\
(0.012)\end{array}$ & $\begin{array}{l}-0.025^{* *} \\
(0.010)\end{array}$ & $\begin{array}{l}-0.058^{* * *} \\
(0.012)\end{array}$ & $\begin{array}{l}-0.041^{* * *} \\
(0.005)\end{array}$ & $\begin{array}{l}-0.067^{* * *} \\
(0.008)\end{array}$ & $\begin{array}{l}-0.068^{* * *} \\
(0.012)\end{array}$ \\
\hline Constant & $\begin{array}{l}4.362^{* * *} \\
(0.275)\end{array}$ & $\begin{array}{l}5.076^{* * *} \\
(0.289)\end{array}$ & $\begin{array}{l}4.370^{* * *} \\
(0.392)\end{array}$ & $\begin{array}{l}6.093^{* * *} \\
(0.276)\end{array}$ & $\begin{array}{l}4.756^{* * *} \\
(0.342)\end{array}$ & $\begin{array}{l}3.759 * * * \\
(0.360)\end{array}$ \\
\hline $\mathrm{N}$ & 1992 & 755 & 534 & 642 & 964 & 995 \\
\hline
\end{tabular}

Note:* $\mathrm{p}<0.05 ; * * \mathrm{p}<0.01 ; * * \mathrm{p}<\mathrm{p} .001$

By themselves, these regression coefficients do not fully capture the cross-national variation in the impact of long-term credit, because the overall effect depends on both the elasticity of debt with respect to duration and the fact that average mortgage duration varies across countries and over time. Fig. 4 illustrates the expected debt/income ratio associated with the average duration of mortgage borrowing in 1995 and 2010 (as reflected in Fig. 3) in order to illustrate the effect of the increasing availability of longerterm credit on household debt levels. Because mortgages are longer on average in the Iberian cases than in France and Germany, the debt attributable to rising maturities is larger, and increased faster in the former - though the "stretching" effect is also surprisingly large in Italy. By 2010, Spanish and Portuguese homeowners stretched their incomes more than twice as far as the French peers. Conversely, as the average duration of mortgage borrowing fell in Germany, the expected debt to income ratio fell (though the change 
Table 7

Determinants of mortgage/service income ratio (OLS estimates; bootstrap standard errors in parentheses).

\begin{tabular}{|c|c|c|c|c|c|c|}
\hline & France & Germany & Italy & Netherlands & Portugal & Spain \\
\hline Duration & $\begin{array}{l}0.023^{* * *} \\
(0.005)\end{array}$ & $\begin{array}{l}0.007 \\
(0.006)\end{array}$ & $\begin{array}{l}0.002 \\
(0.008)\end{array}$ & $\begin{array}{l}-0.002 \\
(0.006)\end{array}$ & $\begin{array}{l}-0.002 \\
(0.004)\end{array}$ & $\begin{array}{l}0.020 * * * \\
(0.005)\end{array}$ \\
\hline Adjustable rate & $\begin{array}{l}0.100 \\
(0.057)\end{array}$ & $\begin{array}{l}-0.013 \\
(0.105)\end{array}$ & $\begin{array}{l}0.088 \\
(0.072)\end{array}$ & $\begin{array}{l}-0.040 \\
(0.109)\end{array}$ & $\begin{array}{l}0.003 \\
(0.076)\end{array}$ & $\begin{array}{l}0.118 \\
(0.083)\end{array}$ \\
\hline Refinanced & $\begin{array}{l}0.255^{* * *} \\
(0.062)\end{array}$ & $\begin{array}{c}-0.032 \\
(0.131)\end{array}$ & $\begin{array}{l}0.075 \\
(0.167)\end{array}$ & $\begin{array}{l}0.260 \\
(0.139)\end{array}$ & $\begin{array}{l}0.481 \\
(0.357)\end{array}$ & $\begin{array}{l}0.425^{*} \\
(0.178)\end{array}$ \\
\hline Adjust. x Refin. & $\begin{array}{l}0.341^{* *} \\
(0.129)\end{array}$ & $\begin{array}{l}-0.216 \\
(0.220)\end{array}$ & $\begin{array}{l}-0.321 \\
(0.286)\end{array}$ & $\begin{array}{l}0.091 \\
(0.119)\end{array}$ & $\begin{array}{l}0.106 \\
(0.098)\end{array}$ & $\begin{array}{l}0.522^{* * *} \\
(0.150)\end{array}$ \\
\hline Second mortgage & $\begin{array}{l}0.073 \\
(0.083)\end{array}$ & $\begin{array}{l}0.057 \\
(0.160)\end{array}$ & $\begin{array}{l}0.080 \\
(0.156)\end{array}$ & $\begin{array}{l}0.195 \\
(0.119)\end{array}$ & $\begin{array}{l}0.126 \\
(0.079)\end{array}$ & $\begin{array}{l}0.209 \\
(0.172)\end{array}$ \\
\hline Additional borrowing & - & $\begin{array}{l}0.175 \\
(0.138)\end{array}$ & - & - & $\begin{array}{l}0.249^{* * *} \\
(0.068)\end{array}$ & - \\
\hline Loan purpose & - & $\begin{array}{c}-0.237 \\
(0.134)\end{array}$ & $\begin{array}{l}-0.080 \\
(0.156)\end{array}$ & $\begin{array}{l}0.024 \\
(0.173)\end{array}$ & $\begin{array}{l}0.101 \\
(0.112)\end{array}$ & $\begin{array}{l}0.044 \\
(0.175)\end{array}$ \\
\hline Refinanced $(>1)$ & $\begin{array}{l}0.450 \\
(0.326)\end{array}$ & $\begin{array}{l}0.624^{* * *} \\
(0.162)\end{array}$ & $\begin{array}{l}0.775 \\
(0.454)\end{array}$ & $\begin{array}{l}0.052 \\
(0.168)\end{array}$ & $\begin{array}{l}-0.208 \\
(0.293)\end{array}$ & $\begin{array}{l}-0.218 \\
(0.485)\end{array}$ \\
\hline Adjust $(>1)$ & $\begin{array}{c}-0.188 \\
(0.163)\end{array}$ & $\begin{array}{l}0.183 \\
(0.252)\end{array}$ & $\begin{array}{l}-0.175 \\
(0.542)\end{array}$ & $\begin{array}{l}0.202 \\
(0.142)\end{array}$ & $\begin{array}{l}0.048 \\
(0.081)\end{array}$ & $\begin{array}{l}0.334 \\
(0.265)\end{array}$ \\
\hline Second mortgage $(>1)$ & $\begin{array}{l}0.096 \\
(0.114)\end{array}$ & $\begin{array}{l}0.344 \\
(0.227)\end{array}$ & $\begin{array}{l}0.136 \\
(0.412)\end{array}$ & $\begin{array}{l}0.001 \\
(0.193)\end{array}$ & $\begin{array}{l}0.531 * * \\
(0.194)\end{array}$ & $\begin{array}{l}0.012 \\
(0.614)\end{array}$ \\
\hline Other properties & $\begin{array}{l}0.039 \\
(0.064)\end{array}$ & $\begin{array}{l}0.057 \\
(0.061)\end{array}$ & $\begin{array}{c}-0.064 \\
(0.046)\end{array}$ & $\begin{array}{l}0.246 \\
(0.250)\end{array}$ & $\begin{array}{l}0.012 \\
(0.036)\end{array}$ & $\begin{array}{l}0.018 \\
(0.046)\end{array}$ \\
\hline Other mortgages & $\begin{array}{l}0.381^{* * * *} \\
(0.058)\end{array}$ & $\begin{array}{l}0.442^{* * *} \\
(0.101)\end{array}$ & $\begin{array}{l}0.447 \\
(0.479)\end{array}$ & $\begin{array}{l}1.484^{* *} \\
(0.485)\end{array}$ & $\begin{array}{l}0.585^{* * *} \\
(0.097)\end{array}$ & $\begin{array}{l}0.607^{* * *} \\
(0.169)\end{array}$ \\
\hline \multicolumn{7}{|l|}{ Control variables } \\
\hline Low income & $\begin{array}{l}0.673^{* * *} \\
(0.117)\end{array}$ & $\begin{array}{l}0.887^{* *} \\
(0.289)\end{array}$ & $\begin{array}{l}0.681^{* *} \\
(0.236)\end{array}$ & $\begin{array}{l}0.723^{* * *} \\
(0.131)\end{array}$ & $\begin{array}{l}0.833^{* * *} \\
(0.091)\end{array}$ & $\begin{array}{l}0.636^{* * *} \\
(0.158)\end{array}$ \\
\hline Top income & $\begin{array}{l}-0.316^{* * *} \\
(0.062)\end{array}$ & $\begin{array}{l}-0.350 * * * \\
(0.097)\end{array}$ & $\begin{array}{l}-0.354^{* * *} \\
(0.084)\end{array}$ & $\begin{array}{l}-0.449 * * * \\
(0.086)\end{array}$ & $\begin{array}{l}-0.632^{* * *} \\
(0.054)\end{array}$ & $\begin{array}{l}-0.495^{* * *} \\
(0.058)\end{array}$ \\
\hline Age 16-34 & $\begin{array}{l}-0.079 \\
(0.075)\end{array}$ & $\begin{array}{l}0.430 * \\
(0.173)\end{array}$ & $\begin{array}{l}-0.104 \\
(0.134)\end{array}$ & $\begin{array}{l}-0.116 \\
(0.158)\end{array}$ & $\begin{array}{l}0.159 * \\
(0.067)\end{array}$ & $\begin{array}{l}0.152^{*} \\
(0.073)\end{array}$ \\
\hline Age 45-54 & $\begin{array}{l}0.002 \\
(0.062)\end{array}$ & $\begin{array}{l}-0.115 \\
(0.096)\end{array}$ & $\begin{array}{l}-0.048 \\
(0.098)\end{array}$ & $\begin{array}{l}-0.341^{* *} \\
(0.108)\end{array}$ & $\begin{array}{l}0.017 \\
(0.058)\end{array}$ & $\begin{array}{l}0.147 \\
(0.078)\end{array}$ \\
\hline Age 55-64 & $\begin{array}{l}-0.024 \\
(0.098)\end{array}$ & $\begin{array}{l}0.122 \\
(0.126)\end{array}$ & $\begin{array}{l}-0.105 \\
(0.155)\end{array}$ & $\begin{array}{l}-0.648^{* * *} \\
(0.147)\end{array}$ & $\begin{array}{l}-0.061 \\
(0.087)\end{array}$ & $\begin{array}{l}0.145 \\
(0.173)\end{array}$ \\
\hline Age 64 & $\begin{array}{l}0.129 \\
(0.138)\end{array}$ & $\begin{array}{l}-0.405^{*} \\
(0.180)\end{array}$ & $\begin{array}{l}0.149 \\
(0.227)\end{array}$ & $\begin{array}{l}-0.749 * * * \\
(0.160)\end{array}$ & $\begin{array}{l}-0.264 \\
(0.164)\end{array}$ & $\begin{array}{l}0.063 \\
(0.135)\end{array}$ \\
\hline Educ: primary & $\begin{array}{l}-0.005 \\
(0.078)\end{array}$ & - & $\begin{array}{c}-0.077 \\
(0.256)\end{array}$ & $\begin{array}{l}-0.230 \\
(0.438)\end{array}$ & $\begin{array}{l}0.145^{* *} \\
(0.053)\end{array}$ & $\begin{array}{l}0.075 \\
(0.107)\end{array}$ \\
\hline Educ: tertiary & $\begin{array}{l}0.103 \\
(0.055)\end{array}$ & $\begin{array}{l}-0.067 \\
(0.071)\end{array}$ & $\begin{array}{l}-0.096 \\
(0.084)\end{array}$ & $\begin{array}{l}0.197^{*} \\
(0.087)\end{array}$ & $\begin{array}{l}-0.190^{*} \\
(0.085)\end{array}$ & $\begin{array}{l}0.005 \\
(0.070)\end{array}$ \\
\hline Single & $\begin{array}{l}-0.143 \\
(0.075)\end{array}$ & $\begin{array}{l}-0.227 \\
(0.155)\end{array}$ & $\begin{array}{l}0.219 \\
(0.139)\end{array}$ & $\begin{array}{l}-0.208^{*} \\
(0.092)\end{array}$ & $\begin{array}{l}0.109 \\
(0.065)\end{array}$ & $\begin{array}{l}0.041 \\
(0.078)\end{array}$ \\
\hline Divorced & $\begin{array}{l}-0.206 * \\
(0.086)\end{array}$ & $\begin{array}{l}0.315^{* *} \\
(0.118)\end{array}$ & $\begin{array}{l}0.215 \\
(0.230)\end{array}$ & $\begin{array}{c}-0.079 \\
(0.163)\end{array}$ & $\begin{array}{l}0.084 \\
(0.081)\end{array}$ & $\begin{array}{l}0.201 \\
(0.157)\end{array}$ \\
\hline No wage earners & $\begin{array}{l}0.197 \\
(0.146)\end{array}$ & $\begin{array}{l}0.091 \\
(0.205)\end{array}$ & $\begin{array}{l}-0.155 \\
(0.275)\end{array}$ & $\begin{array}{l}0.286 \\
(0.209)\end{array}$ & $\begin{array}{l}0.224 \\
(0.137)\end{array}$ & $\begin{array}{l}0.096 \\
(0.098)\end{array}$ \\
\hline One wage earner & $\begin{array}{l}0.106 \\
(0.140)\end{array}$ & $\begin{array}{l}0.321 \\
(0.197)\end{array}$ & $\begin{array}{l}-0.314 \\
(0.279)\end{array}$ & $\begin{array}{l}0.151 \\
(0.202)\end{array}$ & $\begin{array}{l}0.185 \\
(0.111)\end{array}$ & $\begin{array}{l}0.214 \\
(0.122)\end{array}$ \\
\hline Unemployed & $\begin{array}{l}0.137 \\
(0.098)\end{array}$ & $\begin{array}{l}-0.281 \\
(0.205)\end{array}$ & $\begin{array}{l}0.330 \\
(0.274)\end{array}$ & $\begin{array}{l}0.157 \\
(0.310)\end{array}$ & $\begin{array}{l}0.084 \\
(0.100)\end{array}$ & $\begin{array}{l}0.008 \\
(0.104)\end{array}$ \\
\hline Years owned HMR & $\begin{array}{l}-0.023^{* * *} \\
(0.006)\end{array}$ & $\begin{array}{l}-0.014^{*} \\
(0.006)\end{array}$ & $\begin{array}{l}-0.016 * \\
(0.008)\end{array}$ & $\begin{array}{l}-0.025^{* * *} \\
(0.005)\end{array}$ & $\begin{array}{l}-0.021^{* * *} \\
(0.005)\end{array}$ & $\begin{array}{l}-0.020^{*} \\
(0.008)\end{array}$ \\
\hline Constant & $\begin{array}{l}2.499^{* * *} \\
(0.198)\end{array}$ & $\begin{array}{l}2.628^{* * * *} \\
(0.224)\end{array}$ & $\begin{array}{l}3.224 * * * \\
(0.291)\end{array}$ & $\begin{array}{l}3.017^{* * *} \\
(0.333)\end{array}$ & $\begin{array}{l}2.951^{* * *} \\
(0.227)\end{array}$ & $\begin{array}{l}2.408^{* * *} \\
(0.223)\end{array}$ \\
\hline $\mathrm{N}$ & 1946 & 753 & 534 & 642 & 964 & 995 \\
\hline
\end{tabular}

Note:* $\mathrm{p}<0.05 ; * * \mathrm{p}<0.01 ; * * \mathrm{p}<\mathrm{p} .001$

is not statistically significant): unlike homeowners in most other countries, Germans "de-intensified" their engagement with the mortgage market by reducing the duration of borrowing.

Consistent with the financial intensity model, the increasing availability of long-term credit in Europe has allowed homeowners to borrow more in relation to their income, rather than make debt more manageable by reducing monthly payments, as implied by the inclusion model. With two notable exceptions, households' response to longer-term credit is an extremely good predictor of the overall average debt level; indeed, the difference between the expected debt of a household with the average duration of borrowing more than accounts for the total difference between the average debt to income ratios of Iberian households and their French and German peers. However, countries with very high and very low levels of debt (the Netherlands and Italy) are anomalous in this 


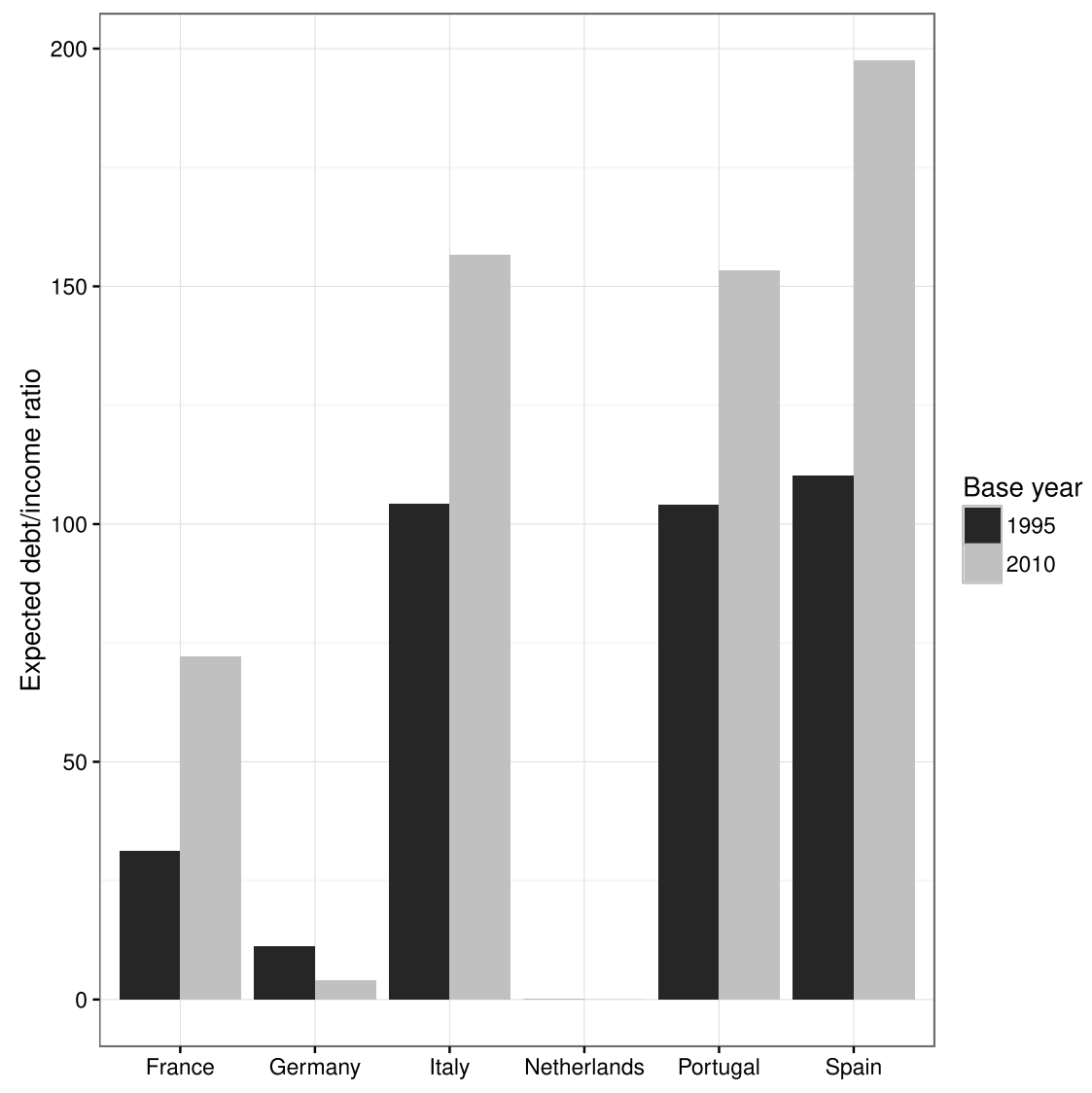

Fig. 4. Expected debt/income ratio due to long-term borrowing.

respect. Though 30 year mortgages have long been the norm in the Netherlands, Dutch households do not seem to use longer-term credit in order to stretch their purchasing power. Conversely, while Italian homeowners have similar average debt burdens to their French and German peers, the expected debt based on "stretching" of households budgets is surprisingly high. We return to these issues below.

\subsection{Interest rates}

The financial inclusion model implies that mortgage contracts which shift risk towards households, such as adjustable interest rates, constrain household borrowing. We find no evidence to support this proposition. Coefficients reflecting the impact of holding an adjustable rate loan are negative, but not significant, in France and Germany, and positive in the other three countries. Moreover, in one high-debt country - Portugal - holders of adjustable rate mortgages have significantly more debt, consistent with the possibility that lenders are willing to lend more to households which absorb more risk, as suggested by the intensity model. These findings call into question the claim that institutions that transfer risk towards households, such as adjustable interest rates, constrain household borrowing and therefore the accessibility of homeownership. European households respond far less to macroeconomic risk than predicted by the inclusion model; one reason for this is that interest rates fell substantially following the creation of the Euro, particularly in Southern Europe. In this macroeconomic context, adjustable interest rates were not a significant constraint on borrowing, and in the case of Portugal, enable households to take on more debt. Together with the fact that (as shown above) adjustable interest rates dominate in high-debt countries, these results give more support to the intensity model.

\subsection{Refinancing}

As argued above, the financial inclusion model implies that the availability of refinancing makes mortgage debt more manageable (for example, by reducing payments), while intensification implies that households use refinancing opportunities to "cash out" equity. Because the purpose of refinancing depends on the interest-rate setting mechanism, we include an interaction effect between these terms. Table 6 shows that in Italy, the Netherlands, Spain and Portugal, homeowners who refinance both fixed and adjustable rate mortgages have significantly more debt. In Spain, these effects also translate into higher mortgage payments, and in no case does refinancing result in higher debt but lower payments. Thus, in all three high-debt cases (but also Italy) mortgage refinancing appears to be a tool for extracting home equity rather than improving loan conditions. This effect is substantial: on average, households 
refinancing an adjustable rate loan borrow between 114\% (in Portugal) and 256\% (in Holland) of their annual income. However, only $4 \%$ of Italian homeowners had refinanced an adjustable rate mortgage, compared to 10\% in Portugal, 14\% in Spain, and 33\% in the Netherlands. As a result, refinancing adjustable rate loans contributed $20 \%$ of income to the average debt level in Spain and $84 \%$ in the Netherlands, but only $7 \%$ in Italy. While the relative intensity of Italian household behavior is surprising, this behavior is confined to a small subset of the homeowning population.

While there is thus little evidence that the goal of refinancing is to reduce monthly payments, households may obtain other improvements in loan conditions. To examine the purpose of refinancing further, we estimated additional models (available on request) capturing the effect of refinancing both fixed and adjustable rate mortgages with interest rates and mortgage duration. In most countries, households obtain some interest rate relief by refinancing, particularly when the resulting loan is at an adjustable interest rate. However, this is not the case in Spain, and weakly so in Portugal. French, German and Dutch homeowners also reduce the duration of their borrowing between two and five years by refinancing. This implies that households in these countries use refinancing to consolidate and reduce the cost of debt, reducing their risk exposure. In contrast, Iberian households use refinancing to extend the life of their debt (in addition to borrowing more, as we have already seen). These results imply that in Spain and Portugal, refinancing is used primarily to cash out equity, with only a modest improvement of loan conditions in Portugal and none in Spain. These results support the intensity model and underscore the importance of examining actual household financial behavior, in addition to the distribution of available financial instruments.

\subsection{Leveraged consumption}

As noted above, refinancing is one of several means of leveraging housing wealth to support current consumption. In France, Italy and Portugal, homeowners who take out a second mortgage have a significantly larger debt burden (in the Netherlands, this effect is significant only at the 0.1 level). Portuguese households also increase their total debt by borrowing additional funds on existing mortgages after purchasing the residence: on average, households that borrow after house purchase hold debt equivalent to an additional $61 \%$ of current income in Portugal. Finally, controlling for these other forms of leverage, use of mortgages for purposes other than home purchase is significantly associated with higher debt in Spain (though the substantive impact on debt is relatively small). Thus, a variety of indicators of leveraging household wealth contribute to higher debt in "high debt" countries; these borrowing behaviors also exist in France, but make a smaller contribution to total debt. Taken together, these various measures of leveraging housing wealth for consumption purposes - refinancing, second mortgages, post-purchase borrowing and the stated purpose of borrowing - contribute a negligible proportion of income in France and Germany but a 19\% in Italy, 23\% in Portugal, $25 \%$ in Spain and $100 \%$ in the Netherlands. Thus, the contribution of leveraged consumption is greatest in the three "high debt" countries, but is also surprisingly high in Italy.

\section{Discussion}

The analysis presented in this paper shows that financial intensification explains a substantial portion of the cross-national variation in household debt in Europe. Households in Spain and Portugal have higher debt than their peers in France and Germany because they use longer mortgages to "stretch" their borrowing capacity and use refinancing, second mortgages and other tools to leverage their housing assets to fund current consumption. As a result, they have higher debt payments and face increased life course and macroeconomic risks. French households also extend their borrowing capacity by taking out longer loans, but because the 30year mortgages typical in "high debt" countries are rare, the overall "stretching" effect is smaller. In both France and Italy the intensification effect is offset by high monthly payments, which result in a faster decline of debt over the life course than in the Iberian cases. ${ }^{12}$ In contrast, German households underwent a process of substantial financial de-intensification during the 2000 s. German mortgages became shorter and bore less risk; unlike households in other countries, German households used refinancing to improve loan conditions without expanding debt. These findings help account for the unique decline in household debt in Germany.

The mortgage contracts that enabled Iberian households to accumulate higher debt burdens were relatively novel in that institutional context. Fig. 3 showed that long-term credit, refinancing opportunities and use of mortgage credit to fund current consumption grew during the past fifteen years. Similarly, Table 1 showed that capital market funding for mortgages, especially in the form of securitization, was comparatively high in these "high debt" countries; because these markets did not exist in these countries prior to the mid-1990s (see European Central Bank, 2009), this represents a dramatic increase. This underscores the importance of incorporating recent changes associated with liberalization and financialization in institutional analysis of household financial behavior. European countries that adopted new financial technologies (made possible by specific regulatory and legal frameworks) saw the largest increase in household debt. Though a full account of the de-intensification process in Germany goes beyond the scope of this paper, the explanation likely lies in the institutional legacy of the covered bond form of mortgage finance and German banks' pursuit of profit opportunities abroad following the introduction of the Euro (Fuller, 2016; Mertens, 2017). In contrast, these results imply that regulations affecting prepayment are far less of a deterrent to refinancing than suggested by previous work, that households can withdraw equity without explicit products, and that adjustable interest rates are not a substantial deterrent to borrowing. We suggest that the growth of securitization markets in Europe is a key factor shaping household debt levels.

\footnotetext{
${ }^{12}$ This observation is based on analysis of the expected debt level over the life course as a function of age and the number of years households have owned their homes.
} 
Nevertheless, the institutional effects measured in this paper do not explain everything about the cross-national variation in household debt in Europe. The low aggregate level of household debt in Italy reflects the limited extension of the mortgage market, probably because of the existence of intra-familial mechanisms of housing provision and the inefficient legal system (Schwartz and Seabrooke, 2009). Our analysis shows that those Italian homeowners who do hold mortgages show a surprisingly intense engagement with financial markets - but there are relatively few such homeowners. Similarly, the extremely high level of household debt in the Netherlands is not well explained by financial intensification behaviors such as income "stretching" and leveraged consumption. While refinancing and equity withdrawal contribute to Dutch households' debt, the substantive contribution of these factors is modest relative to the total debt level. Thus, we do not claim that financial intensification explains high debt levels in the Netherlands. Dutch debt reflects a distinct variety of indebtedness: repayment of substantial debt levels in the Netherlands is spread out over the long term without income "stretching," and monthly payments are moderate. The Dutch model of borrowing is probably well explained by a number of highly specific mortgage market institutions, including generous tax subsidies that incentivize interest-only mortgage contracts, allowing households to maintain high debt burdens over the life course (Vandevyvere and Zenthöfer, 2012). Thus, these results underscore the varieties of indebtedness partially concealed by aggregate debt measures.

\section{Conclusion}

The central theoretical implication of these findings is that financial intensity (and the institutional changes that have made it possible) is an under-appreciated explanation for the cross-national variation in household debt. As argued above, the institutionallyoriented literature seeking to explain this variation, while not ignoring financial intensity, tends to emphasize the inclusion model, according to which differences in homeownership rates are the primary determinant of national debt levels (Prasad, 2013; Schwartz and Seabrooke, 2009; Schelkle, 2012b). Our results suggest that financial intensity is likely a far more important part of the explanation. In other words, households borrowing more, rather than more households borrowing, is the key dynamic underlying the uneven global expansion of household debt. Furthermore, our findings show that mortgage market institutions have changed quickly in some countries (but not others), exposing the limits of previous studies relying on static cross-sectional indexes to measure institutional variation. Theoretically, this implies that more attention is needed to the institutional changes brought about by financial liberalization and globalization in cross-national studies of household debt.

These conclusions raise important questions for sociological analysis of the effects of financialization and the credit boom, suggesting several areas for further research. First, we have not attempted to systematically explain the uneven institutional transformation of mortgage markets in Europe, an important question for researchers. Second, the financial technologies used by banks to fund mortgage lending (such as securitization or covered bonds) are likely a key part of this explanation; this relationship deserves careful scrutiny, though data are limited. Third, while this paper shows that financial intensity is an important determinant of crossnational variations in debt, further research can attempt to pinpoint more precisely the relative contributions of inclusion, extension and intensity models. Finally, the financial intensity model raises important normative issues regarding inequality and credit markets. If, as suggested by our results, the primary impact of a dramatic expansion in the supply of credit was to increase financial intensity with little gain in terms of homeownership rates, then credit expansion seems to have little benefit in terms of inclusiveness. This suggests that expanding credit is an ineffective tool for fostering access to homeownership, despite the fact that political rhetoric often justifies credit expansion in these terms.

\section{Acknowledgments}

Previous versions of this paper were presented at meetings of the American Sociological Association (2017) and Society for SocioEconomics (2015), the "Babies, bonds and buildings" workshop (Budapest; supported by Stiftung Deutsch-Amerikanische Wissenschaftsbeziehungen) and "Financialization and its Consequences" workshop at the Carlos III-Juan March Institute (Madrid). The authors thank the participants in these events for helpful suggestions. Special thanks are due to Neil Fligstein and Herman Schwartz.

\section{Appendix: methodology of counterfactual analysis}

Using the HFCS data, we decomposed each country's population into three groups: non-property owners (subpopulation 1), mortgage holders (subpopulation 2), and property owners without mortgage (subpopulation 3). We then calculated the mean debt and income for each group and its percent share in the total population. The proportion of mortgage holders in the population as a whole is the mortgage market participation rate (MMPR). The MMPR plus the share of property owners without mortgages gives the property ownership rate. Any country's debt/income ratio can be obtained as a weighted average of the debt and income of our three subpopulations. Thus for mean income $I$, mean debt $D$, and population share for each subpopulation $s$, for country $i$ and subpopulation $j$, the debt/income ratio can be obtained from:

$$
\frac{\left(D_{i 1} s_{i 1}\right)+\left(D_{i 2} s_{i 2}\right)+\left(D_{i 3} s_{i 3}\right)}{\left(I_{i 1} s_{i 1}\right)+\left(I_{i 2} s_{i 2}\right)+\left(I_{i 3} s_{i 3}\right)}
$$

Our counterfactual analysis is meant to answer the question: what would happen to the debt/income ratio of country $\mathrm{X}$ if it had the mortgage market participation rate of country Y? For instance, what would happen to France's debt/income if it had the same proportion of homeowners with mortgages as Spain? We answer this question by re-calculating the weighted average described above 
using Spain's subpopulation share numbers $(s)$ but keeping France's debt and income levels for each subpopulation:

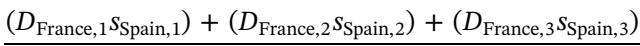

$\left(I_{\text {France }, 1} S_{\text {Spain }, 1}\right)+\left(I_{\text {France }, 2} S_{\text {Spain }, 2}\right)+\left(I_{\text {France }, 3} S_{\text {Spain }, 3}\right)$

\section{References}

Allen, J., Barlow, J., Leal, J., Maloutas, T., Padovani, L., 2008. Housing and Welfare in Southern Europe. John Wiley \& Sons. Andrews, D., Caldera Sánchez, A., Johansson, ^., 2011. Housing Markets and Structural Policies in OECD Countries.

Angelini, V., Laferrere, A., Weber, G., 2013. Home-ownership in Europe: how did it happen? Adv. Life Course Res. 18 , 83-90.

Bordo, M.D., Meissner, C.M., 2012. Does inequality lead to a financial crisis? J. Int. Money Finance 31 (8), $2147-2161$.

Bover, O., Casado, J.M., Costa, S., Caju, P.D., Mccarthy, Y., Sierminska, E., Tzamourani, P., Villanueva, E., Zavadil, T., 2014. The Distribution of Debt across Euro Area

Countries: the Role of Individual Characteristics, Institutions and Credit Conditions. ECB Working Paper Series 1639.

Carruthers, B.G., Ariovich, L., 2010. Money and Credit: a Sociological Approach. (Cambridge: Polity).

Coibion, O., Gorodnichenko, Y., Kudlyak, M., Mondragon, J., 2014. Does Greater Inequality Lead to More Household Borrowing? New Evidence from Household Data. NBER Working Paper 19850. .

Conley, D., Gifford, B., 2006. Home ownership, social insurance, and the welfare state. Sociol. Forum 21 (1), 55-82.

Davis, G.F., 2009. Managed by the Markets: How Finance Re-shaped America. Oxford University Press, Oxford.

European Central Bank, 2009. Housing Finance in the Euro Area. Technical report. European Central Bank, Frankfurt.

Fligstein, N., Goldstein, A., 2015. The emergence of a finance culture in American households, 1989-2007. Socio-Economic Rev. 13 (3), 575-601.

Fuller, G.W., 2015. Who's Borrowing? Credit encouragement vs. Credit mitigation in national financial systems. Polit. Soc. 43 (2), $241-268$.

Fuller, G.W., 2016. The Great Debt Transformation: Households, Financialization, and Policy Responses. Palgrave Macmillan.

Green, R.K., Wachter, S.M., 2005. The American mortgage in historical and international context. J. Econ. Perspect. 19 (4), $93-114$.

HFCN, 2013. The Eurosystem Household Finance and Consumption Survey: Methodological Report for the First Wave.

Immergluck, D., 2009. Foreclosed: High-risk Lending, Deregulation and the Undermining of America's Mortgage Market. Cornell University Press, Ithaca.

International Monetary Fund, 2008. World Economic Outlook: Housing and the Business Cycle. Technical report. International Monetary Fund, Washington D.C.

Kemeny, J., 2005. "The really big trade-off" between home ownership and welfare: castles' evaluation of the 1980 thesis, and a reformulation 25 Years on. Hous. Theory Soc. 22 (2), 59-75.

Krippner, G.R., 2011. Capitalizing on Crisis: the Political Origins of the Rise of Finance. Harvard University Press, Cambridge.

Kumhof, M., Ranciere, R., 2010. Inequality, Leverage and Crises.

Langley, P., 2008. The Everyday Life of Global Finance: Saving and Borrowing in Anglo-america. Oxford University Press, Oxford.

Mertens, D., 2017. Putting âĂŸmerchants of debt' in their place: the political economy of retail banking and credit-based financialisation in Germany. New Polit. Econ. 22 (1), 12-30.

Mian, A., Sufi, A., 2011. House prices, home equity-based borrowing, and the US household leverage crisis. Am. Econ. Rev. 101 (5), $2132-2156$.

Mian, A., Sufi, A., 2014. House of Debt: How They (And You) Caused the Great Recession, and How We Can Prevent it from Happening Again. University of Chicago Press, Chicago.

Prasad, M., 2013. The Land of Too Much: American Abundance and the Paradox of Poverty. Harvard University Press, Cambridge.

Quinn, S., 2010. American Securitization: Finance, Technology and the Politics of Debt. Dissertation. University of California, Berkeley.

Rajan, R.G., 2010. Fault Lines: How Hidden Fractures Still Threaten the World Economy. Princeton University Press, Princeton.

Rugh, J.S., Massey, D.S., 2010. Racial segregation and the American foreclosure crisis. Am. Sociol. Rev. 75 (5), $629-651$.

Schelkle, W., 2012a. A crisis of What? Mortgage credit markets and the social policy of promoting homeownership in the United States and in Europe. Polit. Soc. 40 (1), 59-80.

Schelkle, W., 2012b. In the spotlight of crisis: how social policies create, correct, and compensate financial markets. Polit. Soc. 40 (1), 3-8.

Schwartz, H., 2012. Housing, the welfare state, and the global financial crisis: what is the connection? Polit. Soc. 40 (1), 35-58.

Schwartz, H.M., 2009. Subprime Nation. Cornell University Press, Ithaca.

Schwartz, H.M., Seabrooke, L., 2009. Varieties of residential capitalism in the international political economy: old welfare states and the new politics of housing. In:

Schwartz, H.M., Seabrooke, L. (Eds.), The Politics of Housing Booms and Busts. Palgrave Macmillan, London, pp. 1-27.

Trumbull, G., 2012. Credit access and social welfare: the rise of consumer lending in the United States and France. Polit. Soc. 40 (1), 9-34.

van der Zwan, N., 2014. Making sense of financialization. Socio-Economic Rev. 12 (1), 99-129.

Vandevyvere, W., Zenthöfer, A., 2012. The Housing Market in the Netherlands. European Commission Economic Papers 457. .

Williams, R., Nesiba, R., McConnell, E.D., 2005. The changing face of inequality in home mortgage lending. Soc. Probl. 52 (2), $181-208$. 